\title{
Biological Production of 3-Hydroxypropionic Acid: An Update on the Current Status
}

\author{
Leonidas Matsakas *(i), Kateřina Hrůzová (i), Ulrika Rova ${ }^{(1)}$ and Paul Christakopoulos \\ Biochemical Process Engineering, Division of Chemical Engineering, Department of Civil, Environmental and \\ Natural Resources Engineering, Luleå University of Technology, SE-971 87 Luleå, Sweden; \\ katerina.hruzova@ltu.se (K.H.); ulrika.rova@ltu.se (U.R.); paul.christakopoulos@ltu.se (P.C.) \\ * Correspondence: leonidas.matsakas@ltu.se; Tel.: +46-(0)-920-493043
}

Received: 22 January 2018; Accepted: 9 February 2018; Published: 13 February 2018

\begin{abstract}
The production of high added-value chemicals from renewable resources is a necessity in our attempts to switch to a more sustainable society. 3-Hydroxypropionic acid (3HP) is a promising molecule that can be used for the production of an important array of high added-value chemicals, such as 1,3-propanediol, acrylic acid, acrylamide, and bioplastics. Biological production of 3HP has been studied extensively, mainly from glycerol and glucose, which are both renewable resources. To enable conversion of these carbon sources to $3 \mathrm{HP}$, extensive work has been performed to identify appropriate biochemical pathways and the enzymes that are involved in them. Novel enzymes have also been identified and expressed in host microorganisms to improve the production yields of $3 \mathrm{HP}$. Various process configurations have also been proposed, resulting in improved conversion yields. The intense research efforts have resulted in the production of as much as $83.8 \mathrm{~g} / \mathrm{L} 3 \mathrm{HP}$ from renewable carbon resources, and a system whereby 3-hydroxypropionitrile was converted to $3 \mathrm{HP}$ through whole-cell catalysis which resulted in $184.7 \mathrm{~g} / \mathrm{L} 3 \mathrm{HP}$. Although there are still challenges and difficulties that need to be addressed, the research results from the past four years have been an important step towards biological production of $3 \mathrm{HP}$ at the industrial level.
\end{abstract}

Keywords: 3-hydroxypropionic acid; metabolic engineering; building-block chemicals; glycerol; platform chemicals; Klebsiella pneumoniae; Escherichia coli; Saccharomyces cerevisiae

\section{Introduction}

The use of fossil resources for the production of fuels, chemicals, and materials has caused serious environmental problems, which - together with their imminent depletion-has made the establishment of renewable alternative production methods an important priority. For this reason, development of technologies for the establishment of biorefineries for the production of fuels, chemicals, and materials from renewable resources has been actively pursued to replace the use of fossil resources. Of the different molecules that are projected to be produced through biorefinery-based strategies, 3-hydroxypropionic acid (3HP) holds an important position.

3HP is one of the key building-block chemicals. In the list issued in 2004 and updated in 2010, the United States Department of Energy (DOE) recognized it as one of the 12 top building-block chemicals that can be produced from biomass, ranking it in third position among the molecules selected [1]. It contains two functional groups (a carboxyl group and a $\beta$-hydroxyl group), which makes it attractive to serve as an excellent versatile platform for the production of a variety of high added-value chemicals through chemical modification reactions [1]. The compounds that can be produced from 3HP include 1,3-propanediol, acrylic acid, acrylamide, acrylonitrile, propiolactone, malonic acid, homopolymers, and heteropolymers [2,3]. These compounds have a broad range of applications, and can be used for the production of adhesives, polymers, plastic packaging, fibers, cleaning agents, and resins. Until now, 
they have mainly been produced by the petrochemical industry from fossil resources. However, this is not sustainable, and there is an urgent need to switch to economically and ecologically sound production using renewable resources. Production of these substances from $3 \mathrm{HP}$ is a sustainable solution in itself, but it is also important that the production of $3 \mathrm{HP}$ itself should take place from renewable resources. For example, it has been estimated that production of acrylic acid from $3 \mathrm{HP}$, which is otherwise produced from glycerol, may be $50 \%$ cheaper than petroleum-based acrylic acid production, with a $75 \%$ reduction in greenhouse gas emissions [4]. Much research is being devoted to the biotechnological production of 3HP from renewable resources. To achieve this goal, an intense research effort has been made (1) to identify novel biochemical pathways; and (2) regarding the metabolic engineering of microbial strains to transform them to cell factories capable of producing $3 \mathrm{HP}$ (the two main renewable carbon sources being glycerol and sugars). Moreover, attempts to increase 3HP production titers are also being made through improvements in cultivation techniques. These intense research activities have meant that a lot of research work has been published in the past four years. The aim of the current review is to provide an update on the progress that has occurred in the biotechnological production of $3 \mathrm{HP}$ after 2013, as an update to our previous review article on this matter [3].

\section{Production of 3HP from Glycerol}

The use of glycerol, which is a renewable resource, as starting material for the biotechnological production of $3 \mathrm{HP}$, is a common strategy. It can be obtained as a by-product of biodiesel production. Biodiesel is produced from the transesterification of oils with a short-chain alcohol (mainly methanol) in the presence of a catalyst [5]. During biodiesel production, crude glycerol is generated as by-product in a ratio of about $100 \mathrm{~kg}$ glycerol to 1 ton of biodiesel produced [6]. As the worldwide production of biodiesel is tending to increase, the amounts of crude glycerol that are available will follow the same trend in the future. It is estimated that the production of glycerol will reach $4.2 \times 10^{9} \mathrm{~L}$ in 2020 , and that the world glycerol market will have a value of about 2.52 billion US dollars (USD) [7,8]. Moreover, the oversupply of glycerol leads to a decrease in its price [9]. During 2013, the prices of refined glycerol varied from $900 \mathrm{USD} /$ ton to $965 \mathrm{USD} /$ ton, with the prices of the unrefined crude glycerol being as low as 240 USD/ton [7]. The high quantities of crude glycerol that are produced require its treatment or further use, which, together with the low price, creates an ideal situation for the incorporation of crude glycerol into the biotechnological production of a variety of fuels and chemicals [8,9]. Moreover, upgrading of biodiesel-derived glycerol to high added-value products will boost the economy of the biodiesel production sector [10]. Conversion of glycerol to $3 \mathrm{HP}$ is one of the available options for the utilization of glycerol, and much research effort is being made towards this conversion. Several bacterial strains, such as Klebsiella sp., are capable of natural uptake of glycerol through oxidative or reductive pathways. In the oxidative pathway, this leads to the formation of pyruvate through the Embden-Meyerhof-Parnas pathway, whereas the reductive pathway results in the formation of 1,3-propanediol [11]. Genetic manipulation of the natural glycerol consuming strains can result in the conversion of glycerol to $3 \mathrm{HP}$, through 3-hydroxypropionaldehyde as an intermediate. To achieve this conversion, the genes of either the dha operon or the $p d u$ operon are commonly used, as summarized in the following sections.

\subsection{Production Using Genes That Are Part of the Dha Operon}

The naturally occurring dha operon encodes the necessary enzymes for the conversion of glycerol to 1,3-propanediol. A detailed description of the genes in the dha operon and their action is given in our previous review article [3]. Briefly, the operon mainly consists of genes encoding (1) a glycerol dehydratase, which catalyzes the conversion of glycerol to 3-hydroxypropionaldehyde; (2) a reactivase of the glycerol dehydratase; and (3) a 1,3-propanediol oxidoreductase, which catalyzes the conversion of 3-hydroxypropionaldehyde to 1,3-propanediol, with some structural differences in different microorganisms. Conversion of glycerol to $3 \mathrm{HP}$ using the dha operon is performed in two stages, whereby glycerol is initially converted to 3-hydroxypropionaldehyde through the action of 
the enzyme glycerol dehydratase, followed by conversion of the 3-hydroxypropionaldehyde to 3HP by the action of an aldehyde dehydrogenase (ald) enzyme (Figure 1). A strategy that is commonly employed is to use a microorganism that already possess the dha operon, and genetically modify it to produce $3 \mathrm{HP}$. In that case, the gene encoding the 1,3-propanediol oxidoreductase should be deleted or underexpressed if the co-production of 1,3-propanediol is not wanted, but special care should be taken to maintain a balance between $\mathrm{NADH}$ and $\mathrm{NAD}^{+}$. Regeneration of $\mathrm{NAD}^{+}$is important, as it is required for the action of the ald enzyme. $\mathrm{NAD}^{+}$can be regenerated in the electron transport chain, which requires increased aeration, but the presence of oxygen inhibits the synthesis of coenzyme $\mathrm{B}_{12}$, which is also involved in the process [12]. Moreover, as will be discussed later, oxygen also inactivates the glycerol dehydratase. Regeneration of $\mathrm{NAD}^{+}$can also take place during the conversion of 3-hydroxypropionaldehyde to 1,3-propanediol by the action of the 1,3-propanediol oxidoreductase, which consumes NADH [13]. If the 1,3-propanediol oxidoreductase gene is knocked out, another pathway for $\mathrm{NAD}^{+}$should be found in order to maintain the balance between $\mathrm{NADH}$ and $\mathrm{NAD}^{+}$, such as lactate or acetate formation [12]. On the other hand, co-production of 3HP and 1,3-propanediol can also be desirable, as 1,3-propanediol also has significant applications and these two molecules can be separated easily, due to the presence of different functional groups on the molecules [14].

Another consideration when the dha operon is used is that the first step of the reaction requires coenzyme $B_{12}$, which is produced naturally de novo by some bacterial strains, such as Klebsiella pneumoniae $[15,16]$, whereas other bacteria, such as Escherichia coli, cannot produce it de novo [16]. When the host microorganism is not capable of producing this coenzyme, external addition of it should be included in the cultivation-which will affect the cost of the process. An effort is therefore being made to create new bacterial strains that are capable of producing coenzyme $B_{12}$. Another consideration when using the dha operon is the inactivation of the glycerol dehydratase during the catalysis of glycerol conversion $[17,18]$, so proper expression of the glycerol dehydratase reactivase is important to maintain the activity of glycerol dehydratase and, in turn, 3HP production. Glycerol dehydratase can also be inactivated by oxygen [19], which on the other hand, is necessary for efficient regeneration of the $\mathrm{NAD}^{+}[20]$ that is required for the action of the ald enzymes.

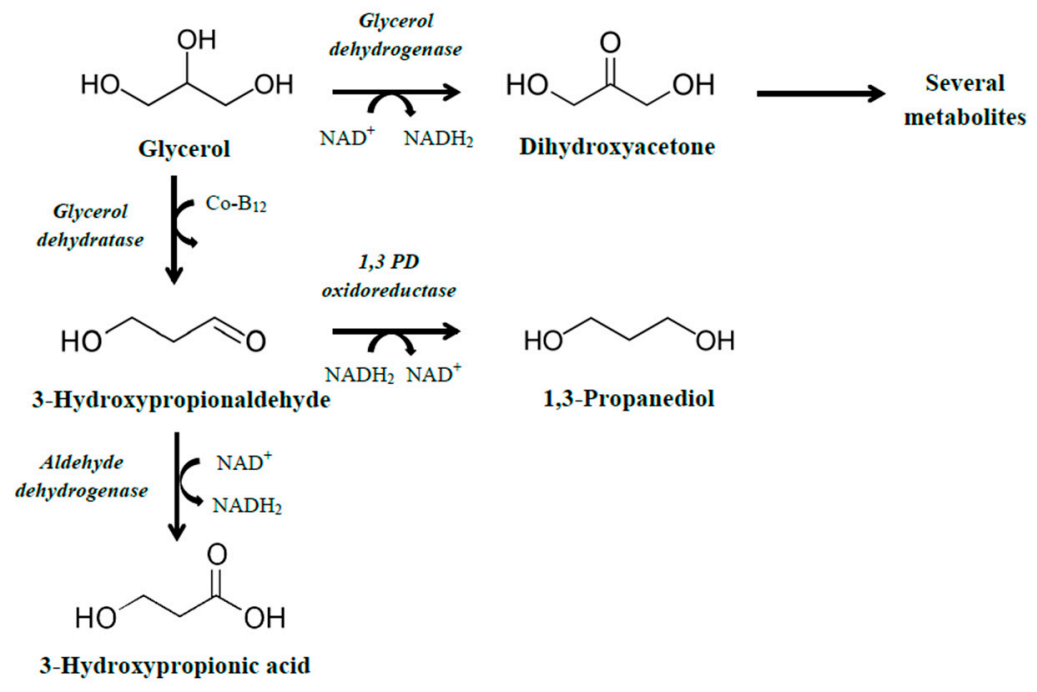

Figure 1. Conversion of glycerol to 3-hydroxypropionic acid (3HP) employing genes from the dha operon.

\subsection{Production Using Genes That Are Part of the Pdu Operon}

The second operon that can be used for the construction of a strain capable of converting glycerol to $3 \mathrm{HP}$ is the $p d u$ operon. In nature, the $p d u$ operon is required for microbial growth on 1,2-propanediol and it can be found in Salmonella and Lactobacillus species [21,22]. First, 1,2-propanediol is converted to propionaldehyde by the action of an AdoCbI-dependent diol dehydratase; this is further converted to 
propionic acid and propanol by the action of the enzymes CoA-dependent aldehyde dehydrogenase, phosphotransacylase, propionate kinase, and alcohol dehydrogenase [22]. Regarding the conversion of glycerol to $3 \mathrm{HP}$ by the enzymes encoded in the $p d u$ operon, more intermediate steps are required than when using the dha operon. Initially, glycerol is converted to 3-hydroxypropionaldehyde by the action of the diol dehydratase, which is followed by its transformation to 3-hydroxypropionyl-CoA by the action of propionaldehyde dehydrogenase. The third step consists of phosphorylation of 3-hydroxypropionyl-CoA to 3-hydroxypropionyl phosphate by phosphate propanoyltransferase. Finally, dephosphorylation of 3-hydroxypropionyl phosphate, by the enzyme propionate kinase, leads to the formation of 3HP (Figure 2).

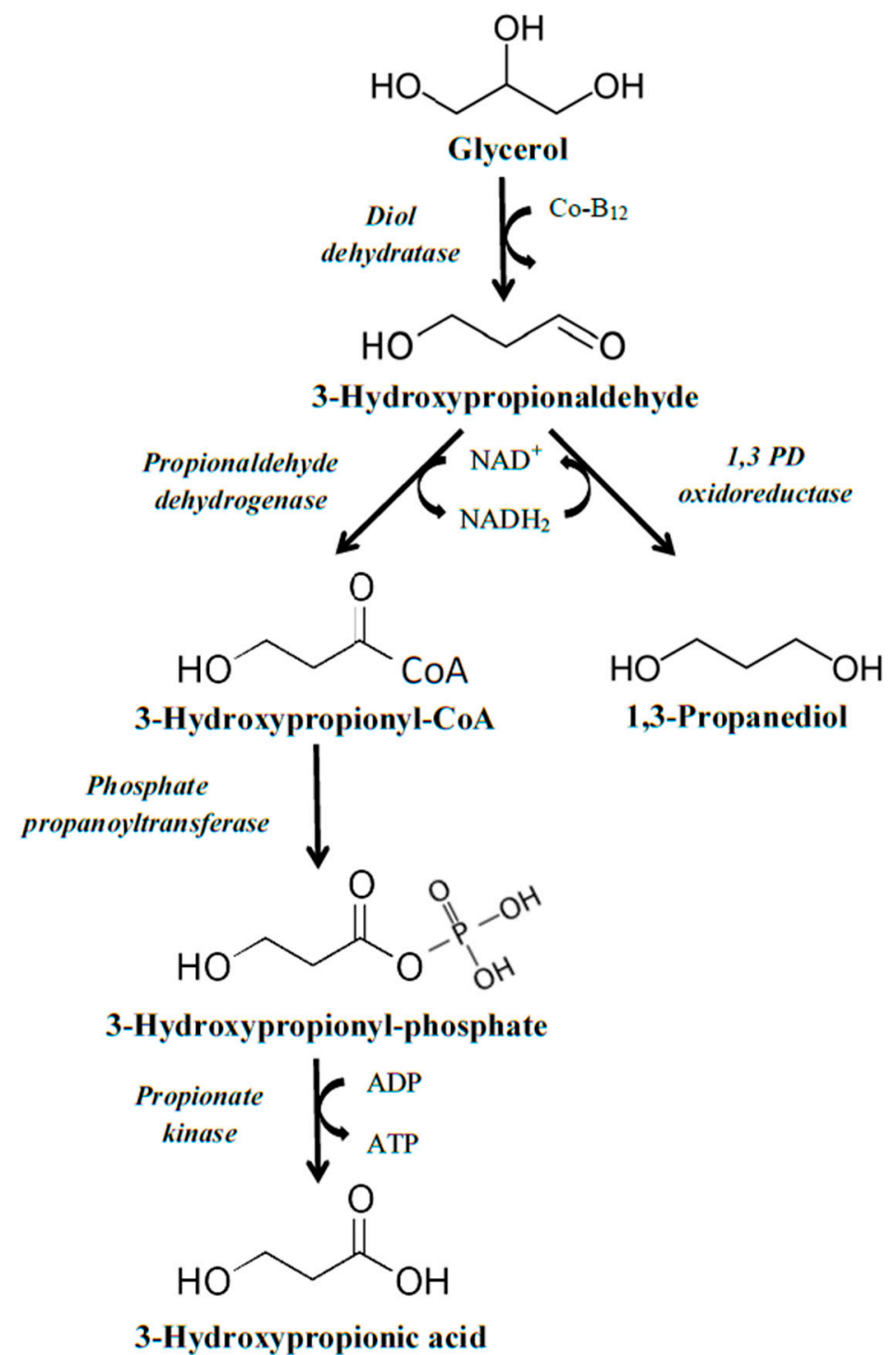

Figure 2. Conversion of glycerol to $3 \mathrm{HP}$ employing genes from the $p d u$ operon.

Similarly to the dha pathway, the use of the $p d u$ pathway presents some challenges that should be taken into account when intending to use it for industrial production of $3 \mathrm{HP}$. As NAD ${ }^{+}$ is required during the second step of the pathway (conversion of 3-hydroxypropionaldehyde to 3-hydroxypropionyl-CoA), an adequate supply of $\mathrm{NAD}^{+}$is necessary. Similar strategies and considerations as described before apply here also, with the co-production of 1,3-propanediol serving 
as a promising solution, as the action of 1,3-propanediol oxidoreductase requires NADH, and therefore, $\mathrm{NAD}^{+}$is regenerated $[23,24]$, maintaining the equilibrium between $\mathrm{NAD}^{+}$and NADH in the process.

\subsection{Engineering of K. pneumoniae Cells for the Conversion of Glycerol to 3HP}

K. pneumoniae is an important candidate for use in the conversion of glycerol to 3HP. K. pneumoniae can naturally produce the required coenzyme $\mathrm{B}_{12}$ de novo, which is important for the economics of the process, as there is no need for external addition of coenzyme $\mathrm{B}_{12}$. Moreover, the dha operon is endogenous in K. pneumoniae, thus minimizing the transfer of required genes when constructing a strain capable of producing 3HP, and has excellent glycerol fermentation capability [25]. On the other hand, as 1,3-propanediol is produced through the dha operon, the genes encoding the 1,3-propanediol oxidoreductase should be deleted, unless co-production of 1,3-propanediol is desired. On the downside, use of K. pneumoniae can potentially give rise to public health concerns. Bacteria of the Klebsiella genus can cause human nosocomial infection, due to their ability to spread rapidly in hospital environments. K. pneumoniae, in particular, is the most important of the Klebsiella genus, from a medical point of view, as it can cause a broad variety of infections, such as urinary tract infections, soft tissue infections, septicemias, and pneumonia in hospital environments [26].

As was discussed before, the balance of the cofactors $\mathrm{NADH}$ and $\mathrm{NAD}^{+}$is important during the conversion of glycerol to $3 \mathrm{HP}$. A strategy to maintain this balance is the co-production of $3 \mathrm{HP}$ and 1,3-propanediol. For example, Su et al. [27] constructed a strain through the heterologous expression of DhaS, a putative ald from Bacillus subtilis, which showed higher specificity toward 3-hydroxypropionic acid than toward other aldehydes (propionaldehyde, benzaldehyde, valeraldehyde, butyraldehyde, and acetaldehyde). The recombinant K. pneumoniae strain was capable of producing $3 \mathrm{HP}$ at $18.0 \mathrm{~g} / \mathrm{L}$, and 1,3-propanediol at $27 \mathrm{~g} / \mathrm{L}$ in $24 \mathrm{~h}$ under non-optimized bioreactor conditions. During the cultivation, a significant amount of lactic acid (36.1 g/L) was also produced (Table 1). The authors suggested that some possible reasons for the low $3 \mathrm{HP}$ concentration might be the competition for $\mathrm{NAD}^{+}$ between 3HP and biomass formation, the toxicity of 3HP toward the host cells, and the non-optimal activity of the ald toward 3-hydroxypropionaldehyde. It is obvious from the above that an adequate supply of $\mathrm{NAD}^{+}$is necessary to achieve a high degree of $3 \mathrm{HP}$ production, and the discovery of more efficient alds is also important.

Table 1. Results of 3HP production from glycerol using K. pneumoniae.

\begin{tabular}{|c|c|c|c|c|}
\hline Genes Transferred & Culture Conditions & $\begin{array}{c}\text { Concentration } \\
(g / L)\end{array}$ & $\begin{array}{l}\text { Productivity } \\
(\mathrm{g} / \mathrm{L} \cdot \mathrm{h})\end{array}$ & Ref. \\
\hline dhaS gene from B. subtilis & $\begin{array}{l}\text { Fed-batch bioreactor } 5 \mathrm{~L}, 3 \mathrm{~L}, \mathrm{pH} 7,37^{\circ} \mathrm{C} \text {, } \\
1.5 \mathrm{vvm}, 400 \mathrm{rpm}\end{array}$ & 18.0 & 0.77 & [27] \\
\hline ald $H$ gene from $E$. coli & $\begin{array}{l}\text { Fed-batch bioreactor, } 5 \mathrm{~L}, 2.8 \mathrm{~L}, \mathrm{pH} \text { 6.8-7.0, } \\
37^{\circ} \mathrm{C} \text {, microaeration } 1.5 \mathrm{vvm}, 400 \mathrm{rpm}\end{array}$ & 48.9 & 1.75 & [28] \\
\hline $\begin{array}{l}\text { Overexpression of } k g s a d h, \\
d h a B \text { and } g d r A B, \text { deletion of } \\
l d h A, f r d A \text {, and } a d h E\end{array}$ & $\begin{array}{l}\text { Fed-batch bioreactor } 1.5 \mathrm{~L}, 1 \mathrm{~L}, \mathrm{pH} 7.5,37^{\circ} \mathrm{C} \text {, } \\
1 \mathrm{vvm}, 400 \mathrm{rpm}\end{array}$ & 43.0 & 0.90 & [12] \\
\hline $\begin{array}{l}\text { PuuC overexpression, deletion } \\
\text { of } l d h 1, l d h 2 \text {, and } p t a\end{array}$ & $\begin{array}{l}\text { Fed-batch bioreactor } 5 \mathrm{~L}, 3 \mathrm{~L}, \mathrm{pH} 7,37^{\circ} \mathrm{C} \text {, } \\
1.5 \mathrm{vvm}, 400 \mathrm{rpm}\end{array}$ & 83.8 & 1.16 & [29] \\
\hline ald $H$ gene from $E$. coli & $\begin{array}{l}\text { Flasks } 250 \mathrm{~mL}, 100 \mathrm{~mL}, 37^{\circ} \mathrm{C} \text {, microaeration, } \\
150 \mathrm{rpm}\end{array}$ & 0.9 & 0.04 & [25] \\
\hline
\end{tabular}

The strategy of co-production was also followed by Huang et al. [28], who expressed the aldH gene from E. coli in K. pneumoniae cells. The authors suggested that the relative amounts of $3 \mathrm{HP}$ and 1,3-propanediol could be controlled by controlling the aeration levels in the culture. Cell growth and production of $3 \mathrm{HP}$ were enhanced by increasing the aeration rate, but 1,3-propanediol production was reduced. Under fully aerobic conditions, however, the dha operon was repressed-resulting in no 
production of either 3HP or 1,3-propanediol. The highest $3 \mathrm{HP}$ concentration $(48.9 \mathrm{~g} / \mathrm{L})$ was reached under microaerobic conditions (1.5 vvm aeration, which resulted in decrease of the dissolved oxygen from $100 \%$ to $0 \%$ in $2.7 \mathrm{~h}$ of culture), with the simultaneous production of $25.3 \mathrm{~g} / \mathrm{L} \mathrm{1,3-propanediol}$ after $28 \mathrm{~h}$ of cultivation in a fed-batch bioreactor. The overall yield of 1,3-propanediol and $3 \mathrm{HP}$ was $0.66 \mathrm{~mol} / \mathrm{mol}$. The authors also demonstrated that the formation of other by-products was also affected by the level of aeration under micro-anaerobic conditions, with the production of lactic acid and acetic acid being enhanced, whereas ethanol and succinic acid production was reduced by increasing the aeration level. Formate production initially increased with increasing levels of aeriation, followed by a sharp decrease when aeration was higher than $0.6 \mathrm{vvm}$. Ko et al. [12] also attempted to control the production of other metabolic by-products, especially of acetic acid, with the aim of improving co-production of 3HP and 1,3-propanediol from the recombinant strain of K. pneumoniae (J2B), which overexpressed the ald gene (encoding alpha-ketoglutaric semialdehyde dehydrogenase- $k g s a d h)$. The methods that they evaluated for acetate reduction were reduction of the glycerol assimilation through the glycolytic pathway, increasing the glycerol flow towards $3 \mathrm{HP}$ and 1,3-propanediol formation, and finally controlling the aeration levels. To improve the co-production, the authors evaluated the deletion and overexpression of several genes. The best results were obtained when the genes encoding lactate dehydrogenase $(\operatorname{ldh} A)$, succinate dehydrogenase $(\operatorname{frd} A)$, and alcohol dehydrogenase $(a d h E)$ were deleted, which-together with the overexpression of $d h a B$ and $g d r A B$-resulted in $3 \mathrm{HP}$ at $43 \mathrm{~g} / \mathrm{L}$ and 1,3-propanediol at $21 \mathrm{~g} / \mathrm{L}$ during fed-batch bioreactor cultivation, with an overall yield of $0.49 \mathrm{~mol} / \mathrm{mol}$. Although these genetic manipulations reduced the amount of acetate, a considerable amount of acetate $(>150 \mathrm{mM})$ had accumulated in the bioreactor by the end of the cultivation.

In another study conducted by Li et al. [29], a systematic optimization of glycerol metabolism took place in order to improve the $3 \mathrm{HP}$ production titers. During this work, different promoters for the overexpression of PuuC (a native ald of K. pneumoniae), which is a key enzyme for 3HP formation, were investigated. Among the promoters tested ( $t a c$ and $l a c$ ), the IPTG-induced tac was found to be the most efficient for overexpression of PuuC. Moreover, 3HP production significantly increased when the synthesis of lactic acid and acetic acid was blocked. Finally, optimization of cultivation parameters, such as aeration (microaerobic conditions), $\mathrm{pH}$ (7.0), and IPTG concentration (0.02 $\mathrm{mM})$ improved the production of $3 \mathrm{HP}$ even further, resulting in a concentration of $83.8 \mathrm{~g} / \mathrm{L}$ with a yield $52 \mathrm{~g} / \mathrm{g}$ after $72 \mathrm{~h}$ of cultivation. To the best of our knowledge, this concentration is the highest reported from glycerol. Although addition of IPTG is not optimal from an economic point of view, the amount required during this work was relatively low compared to what is commonly used (0.5-2 mM IPTG was used for tac-driven gene expression in E. coli, and up to $5 \mathrm{mM}$ IPTG was used for Zymomonas mobilis or Pseudomonas putida) [29]. The high concentration of 3HP demonstrated is an important step towards industrial application.

The most frequent approach for the genetic engineering of novel strains is plasmid insertion (of the required genes) into the host strain. However, as strains containing plasmids are not genetically stable and they require inducers and antibiotics to maintain the selection pressure during cultivation, Wang and Tian [25] tried a different approach for construction of the host strain. More specifically, they constructed a plasmid-free K. pneumoniae strain through chromosomal engineering by replacing the IS1 region in the chromosome with the AD DNA cassette containing the aldH gene from E. coli through homologous recombination. This strain was able to produce $3 \mathrm{HP}$ at $0.9 \mathrm{~g} / \mathrm{L}$ (Table 1 ) in flask cultures when glycerol, at $40 \mathrm{~g} / \mathrm{L}$, was added. Although the concentration of the $3 \mathrm{HP}$ produced was low, this work demonstrated a new approach for the construction of host strains without any need for inducers and antibiotics, which could be very useful for the development of new strains in the future.

Finally, a totally different approach to production of $3 \mathrm{HP}$ from glycerol was studied by Zhao et al. [30]. In their process, they used a two-step approach, where glycerol was first converted to 1,3-propanediol by K. pneumoniae, followed by conversion of 1,3-propanediol to 3HP by Gluconobacter oxydans - a bacterium that incompletely oxidizes a wide range of ketones, organic acids, 
and aldehydes. The final concentration of $3 \mathrm{HP}$ was $60.5 \mathrm{~g} / \mathrm{L}$, and the conversion rate of glycerol to $3 \mathrm{HP}$ was $0.5 \mathrm{~g} / \mathrm{g}$. Moreover, it was the first time that acrylic acid production was reported as a by-product of 3HP production from 1,3-propanediol, at a concentration of approximately $1 \mathrm{~g} / \mathrm{L}$-another high added-value chemical with several applications, such as plastics, adhesives, and coatings.

\subsection{Engineering of E. coli Cells for the Conversion of Glycerol to $3 \mathrm{HP}$}

E. coli is commonly used as a host microorganism for genetic modifications, and there is a wide range of commercial genetic tools available, making it easy to handle with efficient control of gene transfer. In addition, E. coli has a large number of alds in its genome-genes that could be studied and overexpressed for the conversion of glycerol to 3HP. However, the disadvantage of E. coli is that it is not able to produce coenzyme $B_{12}$, leading to the necessity of external addition of this expensive compound, thus affecting process economics and industrial applications.

As when K. pneumoniae is used as the host strain, when using E. coli, one common strategy is to use the genes of the dha operon. As has been discussed, glycerol dehydratase undergoes rapid inactivation, which can result in shutdown of $3 \mathrm{HP}$ production. Niu et al. [31] demonstrated that when the glycerol dehydratase reactivase gene was cloned together with the glycerol dehydratase gene, the $3 \mathrm{HP}$ concentration increased fivefold, due to the prevention of glycerol dehydratase inactivation. In an attempt to increase the 3HP production yield, the authors also expressed the gene encoding the $\mathrm{NAD}^{+}$-regenerating enzyme, glycerol-3-phosphate dehydrogenase (Table 2). However, the concentration of $3 \mathrm{HP}$ was reduced, with increased production of malic acid, due to the lack of NAD ${ }^{+}$. Enhancement of 3HP production by regulation of glycerol metabolism and minimizing of by-product formation was attempted by Jung et al. [4]. During their work, they tried to eliminate the formation of major by-products, such as acetate and 1,3-propanediol, and to increase the metabolic flow of glycerol towards 3HP by upregulating the glycerol kinase $(g l p K)$ and the glycerol facilitator $(g l p F)$, and by deleting the regulatory factor that repressed the use of glycerol $(g l p R)$. After these modifications, the generation of by-products was minimized, and the uptake of glycerol was improved, resulting in a production of $3 \mathrm{HP}$ as high as $42.1 \mathrm{~g} / \mathrm{L}$. The average yield was $0.268 \mathrm{~g} / \mathrm{g}$.

When aiming to produce 3HP through the 3-hydroxypropionaldehyde intermediate, proper balancing of the steps should be attempted, to avoid accumulation of the 3-hydroxypropionaldehyde. 3-Hydroxypropionaldehyde is very toxic for microorganisms, even at concentrations of 15-30 mM, and its accumulation can result in inhibition of $3 \mathrm{HP}$ production, with concentrations as low as $10 \mathrm{mM}$ or even lower having a significant negative effect on growth and enzyme activity [32,33]. One solution to the problem could be the selection of an efficient aldehyde dehydrogenase that would rapidly act on 3-hydroxypropionaldehyde and convert it to 3HP. Based on this strategy, Chu et al. [34] tried 17 candidate aldehyde dehydrogenases for their activity against 3-hydroxypropionaldehyde, with the gabD4 from Cupriavidus necator turning out to be the most effective one. In an attempt to further improve the aldehyde dehydrogenase selected, the authors performed site-directed and saturation mutagenesis, based on homologous modeling. The mutant enzyme obtained had 1.4-fold higher activity compared to the wild type one, and a high $3 \mathrm{HP}$ production of $71.9 \mathrm{~g} / \mathrm{L}$ (with a productivity of $1.8 \mathrm{~g} / \mathrm{L} \cdot \mathrm{h}$ ) was achieved in fed-batch bioreactor culture, which, to the best of our knowledge, is the highest reported concentration reported with $E$. coli as a host growing on glycerol.

Another strategy to avoid 3-hydroxypropionaldehyde accumulation is the use of promoters with different strength in controlling the expression of the enzymes [3], although the number of genetic elements can limit the control over gene expression [33]. The use of the in silico design tool "UTR Designer" has also been proposed; it can provide precise predictions of the translation initiation efficiency [33]. This tool was employed by Lim et al. [33] in their effort to prevent the accumulation of 3-hydroxypropionaldehyde by fine-tuning the expression levels of aldehyde dehydrogenase and glycerol dehydratase. Moreover, they deleted the by-product formation genes, yghD and $a c k A-p t a$, in order to improve metabolic flow towards the formation of 3HP. During flask culture, 3HP formation reached $17.9 \mathrm{~g} / \mathrm{L}$ with a yield of $0.61 \mathrm{~g} / \mathrm{g}$. Following on from these results, the authors tried a fed-batch 
cultivation with the addition of glucose together with the glycerol. Under these conditions, the production of $3 \mathrm{HP}$ increased to $40.5 \mathrm{~g} / \mathrm{L}$ with a yield of $0.97 \mathrm{~g} / \mathrm{g}$. This increase in the yield of $3 \mathrm{HP}$ formation could be explained by the better carbon flow of glycerol towards $3 \mathrm{HP}$ formation, as glucose could cover the needs of cell growth. A different approach for balancing the pathway enzymes to prevent 3-hydroxypropionaldehyde accumulation, and in turn, improve the 3HP production yields, was used by Sankaranarayanan et al. [35]. In their work, they used a synthetic regulatory cassette comprised of varying-strength promoters and bicistronic ribosome-binding sites (RBSs) to control the expression of the genes. Fine-tuning of the levels of expression between the two genes could result in no secretion of 3-hydroxypropionaldehyde, which was achieved when aldehyde dehydrogenase had an expression that was 8-fold higher than that of glycerol dehydratase. This strategy resulted in the engineering of an E. coli strain capable of producing up to $56.4 \mathrm{~g} / \mathrm{L} \mathrm{3HP}$ in a fed-batch bioreactor, with the addition of glucose together with glycerol. The addition of glucose as a co-substrate was also found to improve the activity of the aldehyde dehydrogenase gene, and in turn, improve the $3 \mathrm{HP}$ production yields [36]. Niu et al. [36] reported a 3.5-fold increase in the activity of the enzyme, which improved the $3 \mathrm{HP}$ production in flasks from $3.39 \mathrm{~g} / \mathrm{L}$ (control—no addition of glucose) to $6.80 \mathrm{~g} / \mathrm{L}$. Optimization of the glucose concentration and feeding strategy improved the 3HP production to up to $17.2 \mathrm{~g} / \mathrm{L}$ during fed-batch cultivation. The authors also suggested that addition of glucose reduced the imbalance between the activities of glycerol dehydratase and aldehyde dehydrogenase, as it led to an increase in the activity of aldehyde dehydrogenase.

Table 2. Results of 3HP production from glycerol using E. coli.

\begin{tabular}{|c|c|c|c|c|}
\hline Genes Transferred & Culture Conditions & $\begin{array}{c}\text { Concentration } \\
(\mathrm{g} / \mathrm{L})\end{array}$ & $\begin{array}{l}\text { Productivity } \\
\text { (g/L·h) }\end{array}$ & Ref. \\
\hline $\begin{array}{l}d h a B \text { and } g d r A B \text { from K. pneumoniae } \\
\text { and } k g s a d h \text { from } A \text {. brasilense }\end{array}$ & $\begin{array}{l}\text { Flasks } 250 \mathrm{~mL}, 100 \mathrm{~mL}, 37^{\circ} \mathrm{C} \text {, } \\
200 \mathrm{rpm}\end{array}$ & 5.1 & n.a. & [31] \\
\hline $\begin{array}{l}\text { dhaB and } g d r A B \text { from K. pneumoniae, } \\
\text { aldH from E. coli, overexpression of } \\
g l p F, \text { deletion of } a c k A-p t a, y q h D, \\
\text { and } g l p R\end{array}$ & $\begin{array}{l}\text { Fed-batch bioreactor } 5 \mathrm{~L}, 2 \mathrm{~L}, \\
\mathrm{pH} 7,35^{\circ} \mathrm{C}, 1 \mathrm{vvm}, 500 \mathrm{rpm}\end{array}$ & 42.1 & 1.32 & [4] \\
\hline $\begin{array}{l}\text { dhaB and } g d r A B \text { from } K . \text { pneumoniae, } \\
\text { gabD } 4 \text { from } C \text {. necator with } \\
\text { side-directed mutagenesis, deletion of } \\
\text { yghD and } a c k A-p t a\end{array}$ & $\begin{array}{l}\text { Fed-batch bioreactor } 5 \mathrm{~L}, 2 \mathrm{~L}, \\
\mathrm{pH} 7,35^{\circ} \mathrm{C}, 1 \mathrm{vvm}, 500 \mathrm{rpm}\end{array}$ & 71.9 & 1.8 & [34] \\
\hline $\begin{array}{l}\text { UTR-engineered } d h a B, g d r A B \text { from } \\
\text { K. pneumoniae and } k g s a d h \text { from } \\
\text { A. brasilense, deletion of } y g h D \text { and } \\
\text { ackA-pta }\end{array}$ & $\begin{array}{l}\text { Fed-batch bioreactor } 5 \mathrm{~L} \text { with } \\
\text { the addition of glucose, } 2 \mathrm{~L} \text {, } \\
\text { pH } 7,37^{\circ} \mathrm{C}, 1 \text { vvm, } 500 \mathrm{rpm}\end{array}$ & 40.5 & 1.35 & [33] \\
\hline $\begin{array}{l}d h a B \text { and } g d r A B \text { from K. pneumoniae } \\
\text { and } k g s a d h \text { from } A \text {. brasilense }\end{array}$ & $\begin{array}{l}\text { Fed-batch bioreactor } 1.5 \mathrm{~L} \\
\text { with the addition of glucose, } \\
\mathrm{pH} 7,37^{\circ} \mathrm{C}, 1 \mathrm{vvm}, 650 \mathrm{rpm}\end{array}$ & 56.4 & 1.18 & [35] \\
\hline $\begin{array}{l}d h a B \text { and } g d r A B \text { from K. pneumoniae } \\
\text { and kgsadh from A. brasilense }\end{array}$ & $\begin{array}{l}\text { Fed-batch bioreactor } 5 \mathrm{~L} \text { with } \\
\text { the addition of glucose, } 3 \mathrm{~L}, \\
\text { pH } 6.5,37^{\circ} \mathrm{C}, 450 \mathrm{rpm}\end{array}$ & 17.2 & n.a. & [36] \\
\hline $\begin{array}{l}d h a B \text { and } g d r A B \text { from K. pneumoniae } \\
\text { and } k g s a d h \text { from } A \text {. brasilense }\end{array}$ & $\begin{array}{l}\text { Fed-batch bioreactor } 1.5 \mathrm{~L}, 1 \mathrm{~L}, \\
\mathrm{pH} 7,37^{\circ} \mathrm{C}, 0.5 \mathrm{vvm}, 650 \mathrm{rpm}\end{array}$ & 41.5 & 0.86 & [37] \\
\hline $\begin{array}{l}\text { dhaB and } g d r A B \text { from K. pneumoniae, } \\
\text { AraE from } A . \text { brasilense, conditional } \\
\text { repression of gap } A \text {, deletion of } y q h D\end{array}$ & Flasks, $300 \mathrm{~mL}, 37^{\circ} \mathrm{C}, 150 \mathrm{rpm}$ & 6.06 & 0.13 & [38] \\
\hline $\begin{array}{l}\text { dhaB and } g d r A B \text { from K. pneumoniae, } \\
\text { AraE from A. brasilense, pdu from } \\
\text { K. pneumoniae }\end{array}$ & $\begin{array}{l}\text { Flasks } 250 \mathrm{~mL}, 60 \mathrm{~mL}, \mathrm{pH} \text { 6-7, } \\
\text { 100-250 rpm }\end{array}$ & 5.05 & 0.105 & [39] \\
\hline
\end{tabular}

n.a.: not available.

Not only the presence of 3-hydroxypropionaldehyde, but also high concentrations of 3HP can inhibit the growth of the host microorganisms, thus hindering the production of 3HP. Aiming to identify a 3HP-tolerant E. coli strain, Sankaranarayanan et al. [37] studied nine acid-tolerant strains that efficiently produced various organic acids at high titers. Construction of the $3 \mathrm{HP}$ producing strains was achieved by expressing the dha operon, and an ald from Azospirillum brasilense. Of all the strains 
tested, two showed a high degree of growth in the presence of $25 \mathrm{~g} / \mathrm{L} 3 \mathrm{HP}$, and one of them, E. coli W, outperformed the rest, and produced $41.5 \mathrm{~g} / \mathrm{L} 3 \mathrm{HP}$ with a yield of $0.31 \mathrm{~g} / \mathrm{g}$. During this work, it was found that there are significant differences in $3 \mathrm{HP}$ tolerance among E. coli strains, and this should be taken into account when selecting an appropriate host microorganism.

To improve the metabolic flow of glycerol towards 3HP, other genes of glycerol catabolism are often deleted, which might result in strains with poor growth [38]. To avoid this and at the same time improve the metabolic flow towards 3HP, Tsuruno et al. [38] suggested the use of a metabolic toggle switch (MTS), and tested the conditional repression of the following genes: $g l p K$ (encoding glycerol kinase), tpiA (encoding triosephosphate isomerase), and gapA (encoding glyceraldehyde-3-phosphate dehydrogenase). After testing the three different strains for their efficiency in $3 \mathrm{HP}$ production, it was found that only the strain with the MTS for gapA improved the production of $3 \mathrm{HP}$ to $4.88 \mathrm{~g} / \mathrm{L}$. Deletion of the gene $y q h D$ (whose protein product is responsible for the conversion of 3-hydroxypropionaldehyde to 1,3-propanediol) further improved the concentration of $3 \mathrm{HP}$ to $6.06 \mathrm{~g} / \mathrm{L}$, with a yield of $0.515 \mathrm{~mol} / \mathrm{mol}$.

Finally, another strategy for genetically modifying E. coli was proposed by Honjo et al. [39], who used a dual synthetic pathway for the construction of E. coli strains. More specifically, they transferred the genes from both the $d h a$ and the $p d u$ operons for the construction of one strain, and compared with the results obtained using a strain with only the genes from the dha operon. The strain with both pathways produced $3 \mathrm{HP}$ at $5.05 \mathrm{~g} / \mathrm{L}$, whereas the strain with only the dha operon produced only $2.98 \mathrm{~g} / \mathrm{L} 3 \mathrm{HP}$. The yield was $0.54 \mathrm{~mol} / \mathrm{mol}$. When the strain only had the $p d u$ operon, it produced $1.41 \mathrm{~g} / \mathrm{L}$, thus underpinning the synergistic action of the two pathways in the conversion of glycerol to $3 \mathrm{HP}$.

\subsection{Other Microorganisms}

It is clear that most of the research is focused mainly on either E. coli or K. pneumoniae as host microorganism for the construction of a cell factory capable of producing 3HP from glycerol. However, there are other microorganisms that could be suitable and efficient cell factories for efficient production of 3HP. For example, Lactobacillus reuteri is a good candidate, due to its ability to naturally produce the coenzyme $B_{12}$ and to its high acid tolerance-both of which are required when producing 3HP. Moreover, the $p d u$ operon is endogenous in that specific species [40], minimizing the need for gene transfer. The use of a recombinant $L$. reuteri strain with a mutation in the catabolite repression element (CRE) was investigated by Dishisha et al. [23], to improve the metabolic flux of glycerol to 3HP and 1,3-propanediol. During the flux analysis for the different steps of the $p d u$ operon, it was found that the glycerol dehydration to 3-hydroxypropionaldehyde was ten times faster than the subsequent oxidation and reduction of 3-hydroxypropionaldehyde to 1,3-propanediol and 3HP. Thus, establishment of an optimal feeding rate of glycerol was crucial to avoid 3-hydroxypropionaldehyde accumulation and direct the flux of glycerol towards $3 \mathrm{HP}$ and 1,3-propanediol formation. The final titers were $10.6 \mathrm{~g} / \mathrm{L}$ $3 \mathrm{HP}$ and $9.0 \mathrm{~g} / \mathrm{L} 1,3$-propanediol under anaerobic conditions in the fed-batch bioreactor when resting cells of $L$. reuteri were used (Table 3 ).

The same recombinant strain of L. reuteri was also used for the preparation of crosslinked, cryostructured monoliths that could be used as a biocatalyst for the conversion of glycerol to 3-hydroxypropionaldehyde, 3HP, and 1,3-propanediol [14]. Different crosslinkers were tested for the preparation of monolith columns of resting L. reuteri cells, with only the mixture of synthetic macromolecular structures of activated polyethyleneimine and modified polyvinyl alcohol (Cryo-PEI/PVA) demonstrating enhanced biocatalytic activity, mechanical stability, and sustained viability. Under optimal conditions, $3.3 \mathrm{~g} / \mathrm{L} 3 \mathrm{HP}$ was produced during fed-batch feeding of the immobilized cells. Finally, a two-step process involving the cultivation of L. reuteri and G. oxydans has also been proposed [41]. More specifically, in the first step, the anaerobic cultivation of L. reuteri in fed-batch mode resulted in the production of equimolar quantities of 3HP and 1,3-propanediol, whereas in the second step, the 1,3-propanediol in the cell-free supernatant was selectively oxidized to $3 \mathrm{HP}$ by G. oxydans under aerobic batch cultivation. At the end of the first step, $14 \mathrm{~g} / \mathrm{L} 3 \mathrm{HP}$ and $12 \mathrm{~g} / \mathrm{L} \mathrm{1,3-propanediol} \mathrm{were} \mathrm{produced,} \mathrm{with} \mathrm{the} \mathrm{corresponding} \mathrm{conversion} \mathrm{yields} \mathrm{being} 0.48 \mathrm{~g} / \mathrm{g}$ and 
$0.42 \mathrm{~g} / \mathrm{g}$, respectively. Finally, the oxidation in the second step resulted in the quantitative conversion of 1,3-propanediol to $3 \mathrm{HP}$, with a final $3 \mathrm{HP}$ concentration of $23.6 \mathrm{~g} / \mathrm{L}$ and an overall conversion yield of glycerol to $3 \mathrm{HP}$ of approximately $1 \mathrm{~mol} / \mathrm{mol}$.

Another host strain that has been used is Bacillus subtilis, which shows high growth rates, and is a non-pathogenic microorganism classified as GRAS (generally recognized as safe) [42]. The first attempt to use this host microorganism for 3HP was described by Kalantari et al. [42]. The constructed strain performed well in shaker flasks, producing up to $10 \mathrm{~g} / \mathrm{L}$ with average yield $0.79 \mathrm{~g} / \mathrm{g}$, and showing good tolerance towards the 3HP produced. One drawback of the use of this strain as host is the lack of any native ability to produce the coenzyme $\mathrm{B}_{12}$ (as with E. coli); the authors suggested that this can be solved by transferring the necessary genes from Bacillus megaterium. This work demonstrated that Bacillus strains can also be used as cell factories for 3HP production, and more work using these cells will probably be conducted in the future.

Table 3. Results of 3HP production from glycerol using other host microorganisms.

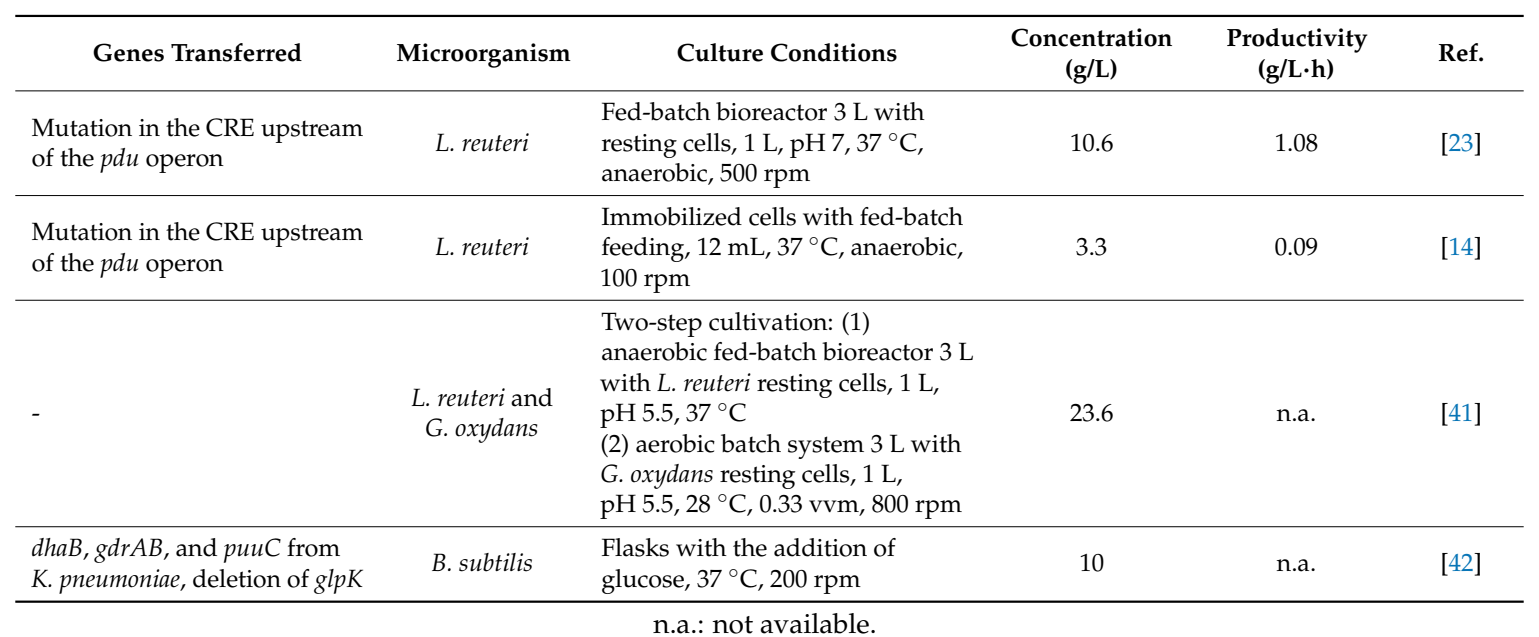

\section{Production of 3HP from Sugars}

Glucose and other sugars (such as xylose) are another source of renewable raw materials for the cultivation of microorganisms when aiming to produce 3HP. Commonly used sources of sugar include sucrose from sugar beet and sugar cane, and glucose from the hydrolysis of corn starch. Due to the fact that these sources of sugar can also serve as food and animal feed, the use of sugars from lignocellulose presents an attractive alternative. Sources of lignocellulosic biomass include agricultural wastes and by-products, forest biomass, energy crops, and municipal waste [43-45]. The use of lignocellulosic materials as a source of fermentable sugars requires a pretreatment step (to disrupt the rigid structure of lignocellulosic biomass), followed by enzymatic hydrolysis of the insoluble carbohydrates in order to release soluble sugars. Several pretreatment methods have been proposed in the literature, which can be classified as physical, physicochemical, chemical, and biological [46]. The different pretreatment methods have shown varied efficiency against lignocellulosic biomass, with the source of the biomass affecting the chosen pretreatment parameters.

Regarding the use of sugars (mainly glucose) as carbon source for the production of $3 \mathrm{HP}$, several different pathways have been proposed. Different research groups have made significant progress in this field by intensively studying some of these pathways. On the other hand, some other predicted pathways have turned out to not be efficient enough when transferred to host microorganisms. 


\subsection{Pathways for the Conversion of Sugars (Mainly Glucose) to 3HP}

\subsubsection{The Malonyl-CoA Pathway}

To the best of our knowledge, malonyl-CoA pathway is currently one of the most investigated pathways for $3 \mathrm{HP}$ production. In this case, glucose is transformed through glycolysis to acetyl-CoA, which is then converted to malonyl-CoA by acetyl-CoA carboxylase. Malonyl-CoA reductase converts malonyl-CoA to 3HP thought a malonate semialdehyde intermediate [47] (Figure 3).

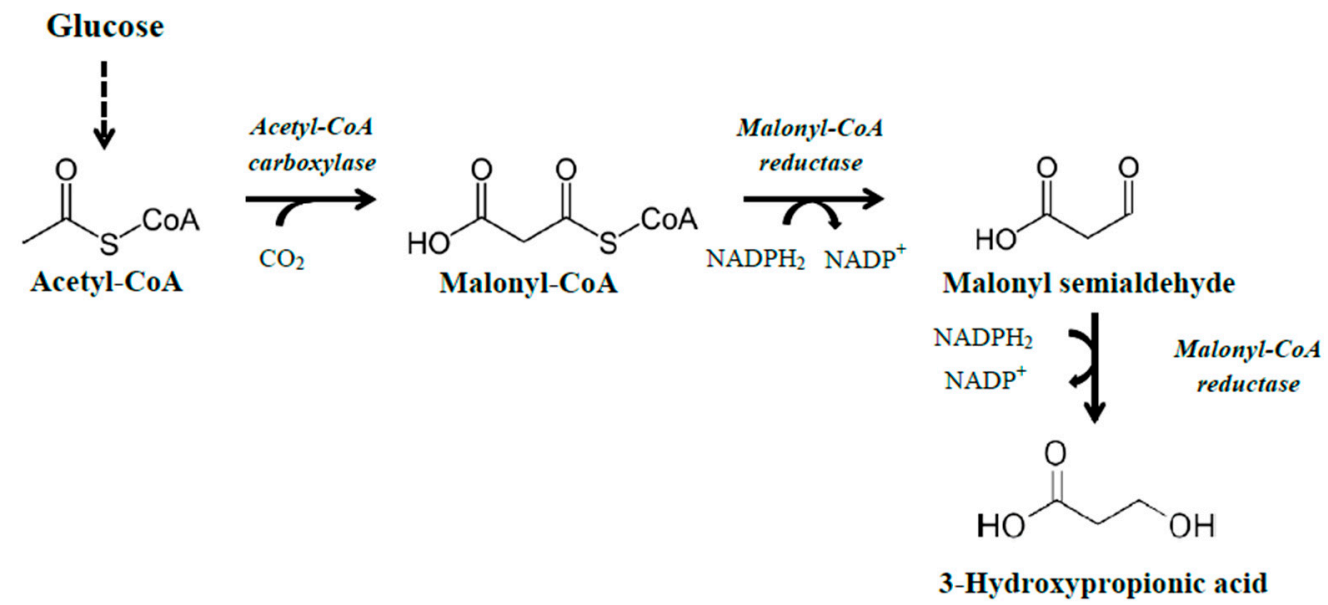

Figure 3. Conversion of glucose to $3 \mathrm{HP}$ through the malonyl-CoA pathway.

\subsubsection{The $\beta$-Alanine Pathway}

The main precursor of this pathway is aspartate, which is produced from fumarate (an intermediate of the citrate cycle). For this reason, it is advantageous to use a strain capable of overproduction of fumarate and of expressing a highly active aspartase, the enzyme responsible for the transformation of fumarate to aspartate. The next step is the transformation of aspartate to $\beta$-alanine by the action of aspartate- $\alpha$-decarboxylase, followed by cleavage of the amino group of $\beta$-alanine by $\beta$-alanine-pyruvate aminotransferase or $\gamma$-aminobutyrate transaminase, resulting in malonic semialdehyde formation [48]. The last step is the conversion of malonic semialdehyde to $3 \mathrm{HP}$ by the action of malonic semialdehyde reductase, 3-hydroxypropionate dehydrogenase, or 3-hydroxyisobutyrate dehydrogenase [49] (Figure 4). Theoretically, the yields achieved through the $\beta$-alanine intermediate pathway should be higher than the yields obtained through the malonic intermediate pathway, as the malonic pathway is highly oxygen-dependent and requires high levels of ATP for acetyl-CoA synthesis [49].

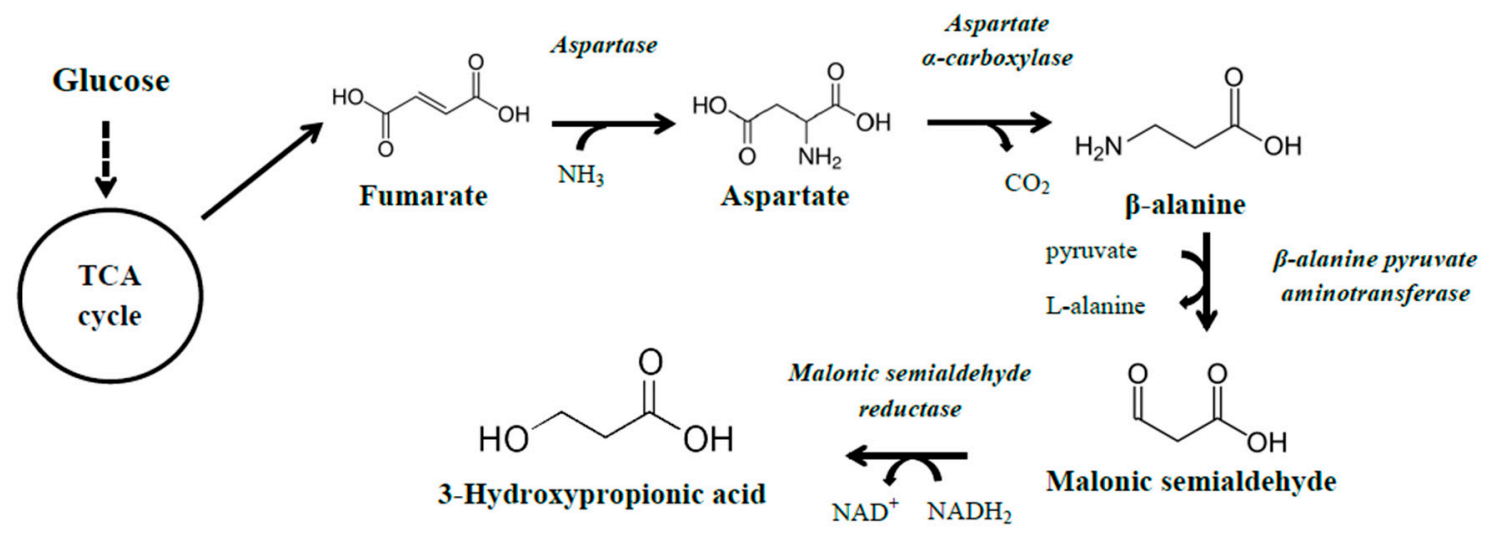

Figure 4. Conversion of glucose to $3 \mathrm{HP}$ through the $\beta$-alanine pathway. 


\subsubsection{The Propionyl-CoA Pathway}

Another option is the conversion of glucose to 3HP through the intermediate propionyl-CoA, which was initially reported in the yeast Candida rugosa strain NPA-1 [50]. In this pathway, succinic acid can be produced from glucose and converted to propionic acid by the action of succinate decarboxylase, followed by conversion of propionate to propionyl-CoA by propionyl-CoA synthetase. Propionyl-CoA is then converted to acryloyl-CoA by the enzyme propionyl-CoA dehydrogenase. In the next step, the acryloyl-CoA is converted to 3-hydroxypropionyl-CoA by 3-hydroxypropionyl-CoA dehydratase, and finally, to $3 \mathrm{HP}$ through the action of the enzyme propionate-CoA transferase or the enzyme 3-hydroxyisobutyryl-CoA hydrolase [47,51] (Figure 5).

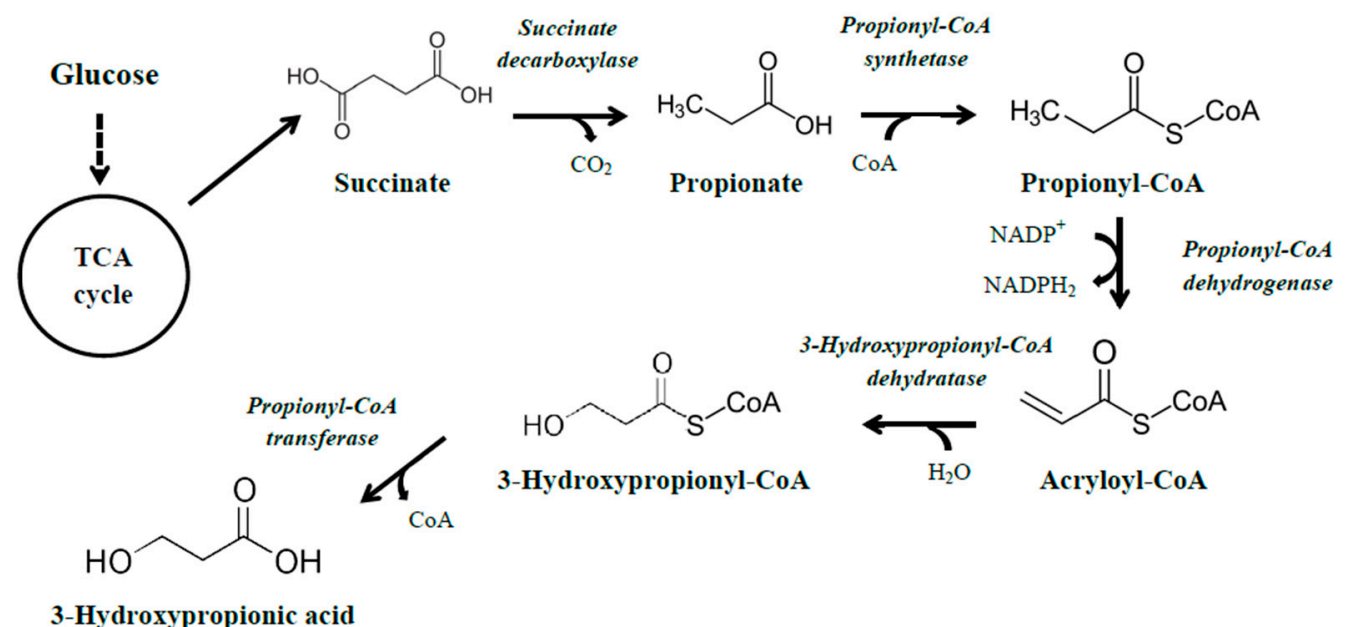

Figure 5. Conversion of glucose to 3HP through the propionyl-CoA pathway.

\subsubsection{The Glycerate Pathway}

The glycerate pathway is another option that has been proposed for the conversion of glucose to $3 \mathrm{HP}$, but to the best of our knowledge, this pathway has not yet been constructed in a host microorganism. The pathway was proposed by Burgard and Van Dien [52]. In this proposed pathway, glucose is converted initially to 3-phosphate-glycerate, followed by its conversion to glycerate and malonate semialdehyde by the action of the enzymes 3-phosphate-glycerate phosphatase and glycerate dehydratase, respectively. Finally, malonate semialdehyde is converted to $3 \mathrm{HP}$ by $3 \mathrm{HP}$ dehydrogenase.

\subsubsection{The Lactate Pathway}

Another proposed pathway that has not yet been constructed in host cells is through a lactate intermediate. However, this pathway was found to be thermodynamically unfavorable [48]. Here, the predicted conversion of lactate leads to 3HP through lactate-CoA, acrylyl-CoA, and 3-hydroxypropionyl-CoA by the action of CoA transferase, lactyl-CoA dehydratase, and 3-hydroxypropionyl-CoA dehydratase, respectively. Finally, conversion of 3-hydroxypropionyl-CoA to $3 \mathrm{HP}$ can be performed by one of the following three enzymes: 3-hydroxypropionyl-CoA hydrolase, CoA transferase, or 3-hydroxyisobutyryl-CoA hydrolase.

\subsubsection{Use of a Glycerol Intermediate}

Another option to convert glucose (or other sugars) to $3 \mathrm{HP}$ is by initially producing glycerol from the central metabolism, and finally, converting the glycerol to 3HP with strategies that have been established for glycerol, instead of directly converting the glucose [53]. 


\subsection{Use of E. coli as a Host Microorganism}

As discussed previously, E. coli is a very commonly used microorganism when it comes to metabolic engineering for the construction of a microbial cell factory, and it has been used extensively for metabolic engineering aimed at 3HP production. On the other hand, the lack of the ability to naturally produce coenzyme $\mathrm{B}_{12}$, which is required for the action of some enzymes involved in the pathways of glycerol conversion to $3 \mathrm{HP}$, is an important drawback. On the other hand, production of $3 \mathrm{HP}$ using the malonyl-CoA pathway is coenzyme $\mathrm{B}_{12}$-independent, and presents a promising alternative when using E. coli cell factories. As discussed previously, the malonyl-CoA pathway starts with the conversion of acetyl-CoA to malonyl-CoA by the enzyme acetyl-CoA carboxylase, and optimal expression and activity of this enzyme is important. Cheng et al. [54] constructed this route in E. coli by expressing the acetyl-CoA carboxylase from Corynebacterium glutamicum, and the malonyl-CoA reductase from Chloroflexus aurantiacus. To improve the function of the acetyl-CoA carboxylase, the authors added biotin and $\mathrm{NaHCO}_{3}$ (to provide $\mathrm{CO}_{2}$ for the carboxylation of acetyl-CoA). Under optimal conditions, $1.8 \mathrm{~g} / \mathrm{L} 3 \mathrm{HP}$ was produced in flasks with a yield of $0.18 \mathrm{~g} / \mathrm{g}$. Scale-up of the process in a fed-batch bioreactor improved the titers obtained to $10.08 \mathrm{~g} / \mathrm{L}$ (Table 4). It was proposed that low yields of 3HP through the malonyl-CoA pathway can be caused by functional imbalance of the two fragments of the malonyl-CoA reductase $(m c r)$, namely the $m c r-c$ and $m c r-n$ fragments [55]. The $m c r$ catalyzes the conversion of malonyl-CoA to $3 \mathrm{HP}$ through malonate semialdehyde, with the $m c r-c$ fragment catalyzing the first step and the $m c r-n$ fragment catalyzing the second. Liu et al. [55] tried to minimize the functional imbalances between the two fragments by employing directed evolution tools, aiming to enhance the action of the $m c r-c$ fragment and then fine-tune the levels of expression of the $m c r-n$ fragment. The newly engineered strain performed well during fed-batch cultivation on glucose, reaching a $3 \mathrm{HP}$ production of to $40.6 \mathrm{~g} / \mathrm{L}$, with a conversion yield of $0.19 \mathrm{~g} / \mathrm{g}$.

In another study, the $\beta$-alanine pathway was constructed in E. coli cells [49]. The authors used a previously developed strain, which was capable of producing $\beta$-alanine [56], to construct the pathway towards 3HP. Based on this strain, the authors tested several downstream enzymes for their efficiency regarding 3HP production [49]. Among the different combinations, the most promising genes were the $y d f G$ from $E$. coli (encoding a malonic semialdehyde reductase) and the pa0132 from Pseudomonas aeruginosa (encoding a $\beta$-alanine pyruvate transaminase). Fine-tuning of other genes related to the pathway (such as overexpression of $p p c$ gene, encoding phosphoenolpyruvate carboxylase, and replacement of the native promoter with the strong tac promoter for the $s d h C$ gene, encoding a succinate dehydrogenase) resulted in the production of $31.1 \mathrm{~g} / \mathrm{L} 3 \mathrm{HP}$, with a yield of $0.423 \mathrm{~g} / \mathrm{g}$.

Table 4. Results of 3HP production from glucose using E. coli as host microorganism.

\begin{tabular}{|c|c|c|c|c|}
\hline Genes Transferred & Culture Conditions & $\begin{array}{c}\text { Concentration } \\
(\mathrm{g} / \mathrm{L})\end{array}$ & $\begin{array}{l}\text { Productivity } \\
(\mathrm{g} / \mathrm{L} \cdot \mathrm{h})\end{array}$ & Ref. \\
\hline $\begin{array}{l}\text { acc from } C \text {. glutamicum and } m c r \text { from } \\
\text { C. aurantiacus }\end{array}$ & $\begin{array}{l}\text { Fed-batch bioreactor } 5 \mathrm{~L}, 2.5 \mathrm{~L}, \\
\mathrm{pH} 7,37^{\circ} \mathrm{C}, 1 \mathrm{vvm}\end{array}$ & 10.1 & 0.28 & [54] \\
\hline $\begin{array}{l}A c c A D B C, m c r \text { with enhanced activity of } \\
\text { the } m c r-c \text { fragment and tuning of the } \\
\text { expression levels of } m c r-n \text { fragment }\end{array}$ & $\begin{array}{l}\text { Fed-batch bioreactor } 5 \mathrm{~L}, 2 \mathrm{~L}, \\
\text { pH } 7,37^{\circ} \mathrm{C}\end{array}$ & 40.6 & 0.56 & {$[55]$} \\
\hline $\begin{array}{l}\text { dhaB and dhaR from Lactobacillus brevis, } \\
\text { aldhH from Pseudomonas aeruginosa, gpd } 1 \\
\text { and } g p p 2 \text { from } S \text {. cerevisiae, deletion of } \\
p t s G, g l p K \text { and } y q h D, \text { overexpression of } \\
x y l R \text { operon }\end{array}$ & $\begin{array}{c}\text { Fed-batch bioreactor } 2.5 \mathrm{~L} \text { with } \\
\text { co-conversion of glucose and } \\
\text { xylose, } 1 \mathrm{~L}, 37^{\circ} \mathrm{C}>25^{\circ} \mathrm{C}, 1 \mathrm{vvm} \text {, } \\
600-1300 \mathrm{rpm}\end{array}$ & 29.7 & 0.54 & [57] \\
\hline
\end{tabular}

A different approach to conversion of glucose to 3HP would be to take advantage of the naturally produced glycerol in the central metabolism of the host and construct a pathway for the conversion of glycerol to 3HP. In this way, both glucose and xylose (two of the main sugars of lignocellulosic 
biomass) can be used and channeled to glycerol through glycolysis and the pentose phosphate pathway, respectively. In order to improve the glycerol production yields, Jung et al. [57] constructed an E. coli strain by initially expressing the genes encoding glycerol-3-phosphate dehydrogenase (gpd1) and glycerol-3-phosphatase ( $g p p 2$ ) from S. cerevisiae. To achieve co-utilization of xylose and glucose, the ptsG gene (encoding the phosphoenolpyruvate:sugar-transferring system) was deleted, and the $x y l R$ operon was overexpressed. The new strain was capable of simultaneously consuming glucose and xylose, and produce glycerol with a yield of $0.48 \mathrm{~g} / \mathrm{g}$. Finally, when the pathway for the conversion of glycerol to $3 \mathrm{HP}$ was constructed, $3 \mathrm{HP}$ production of $29.7 \mathrm{~g} / \mathrm{L}$ was accomplished with an overall yield of $0.36 \mathrm{~g} / \mathrm{g}$.

\subsection{Use of S. cerevisiae as a Host Microorganism}

Regarding the use of glucose as carbon source, the yeast $S$. cerevisiae is a very promising candidate, as it is very robust, is easy to handle, and described as GRAS. Another positive characteristic of this yeast is its high tolerance of low $\mathrm{pH}$ values, which can result from accumulation of $3 \mathrm{HP}[58,59]$. To permit conversion of glucose to $3 \mathrm{HP}$, the malonyl-CoA pathway was also constructed in S. cerevisiae cells [59]. This was done by expressing multiple copies of the $\mathrm{mor}$ gene from C. aurantiacus and mutated acc1 genes. Moreover, in an attempt to improve the supply of acetyl-CoA, the native pyruvate decarboxylase $p d c 1$ gene and the aldehyde dehydrogenase ald 6 gene were overexpressed together with the expression of the acetyl-CoA synthase gene $\left(a_{c s}^{L 641 P}\right)$ from Salmonella enterica; these modifications increased the $3 \mathrm{HP}$ titer by $80 \%$. Finally, the intracellular NADPH, which is required for the action of the $m c r$, was increased by transferring the NADP-dependent glyceraldehyde-3-phosphate dehydrogenase gene (gapdh) from Clostridium acetobutylicum. The strain constructed produced 9.8 g/L 3HP with a yield of 13\% C-mol/C-mol (Table 5).

In another study with S. cerevisiae as host microorganism, the $\beta$-alanine pathway-which was identified through metabolic modeling to be the most attractive pathway from an economic point of view-was constructed [48]. De novo $\beta$-alanine synthesis was performed by the action of a $\beta$-alanine-pyruvate aminotransferase (bapat) from Bacillus cereus (yhxA gene), which is a newly used bapat enzyme. The authors examined the effect on 3HP production of different combinations of the $y h x A$ gene (or another bapat gene from Pseudomonas putida) with various 3-hydroxypropionate dehydrogenase (hpdh) and 3-hydroxyisobutyrate dehydrogenase (hibadh), the most efficient combination being $y h x A$ with the hpdh from E. coli (ydfG gene). Different aspartate-1-decarboxylases (panD) were also tested, the most promising being the one derived from Tribolium castaneum. Finally, improvement of the production yields was achieved by improving the supply of L-aspartate by overexpressing a native cytoplasmic aspartate aminotransferase (aat2) and two pyruvate carboxylases (pyc1, pyc2 genes). The strain that was constructed performed well in fed-batch bioreactors, producing $13.7 \mathrm{~g} / \mathrm{L} 3 \mathrm{HP}$ with a conversion yield of $0.14 \mathrm{C}-\mathrm{mol} / \mathrm{C}-\mathrm{mol}$.

Apart from glucose, xylose is also an important sugar that can be derived from lignocellulosic biomass, and it would be important to incorporate it in the $3 \mathrm{HP}$ production process. One attempt to convert xylose to $3 \mathrm{HP}$ in S. cerevisiae was conducted by Kildegaard et al. [60] by incorporating either the malonyl-CoA pathway or the $\beta$-alanine pathway (using two approaches, one NADH-dependent route and one NADPH-dependent route) in a xylose-utilizing strain. The three different pathways were tested with the yeast growing on glucose or xylose, and the malonyl-CoA route gave the best results on glucose, and the NADPH-dependent $\beta$-alanine pathway resulted in the highest $3 \mathrm{HP}$ yields from xylose. The second route was constructed by expressing two pyruvate carboxylases (pyc1 and pyc2), a bapat from B. cereus, a panD gene from T. castaneum, and the NADPH-dependent hpdh from E. coli (ydfG gene). The strain performed well on xylose, producing $1.8 \mathrm{~g} / \mathrm{L}$ during flask culture, which increased to $6.1 \mathrm{~g} / \mathrm{L}$ when the culture was performed in batch bioreactors. Fed-batch cultivation further improved $3 \mathrm{HP}$ production to $7.4 \mathrm{~g} / \mathrm{L}$, with an overall yield of $29 \% \mathrm{C}-\mathrm{mol} / \mathrm{C}-\mathrm{mol}$. Although the concentration was relatively low, the results of this work are very promising, as glucose and xylose are two major sugars in lignocellulosic biomass, and further optimization of the strain would enable culture on lignocellulosic hydrolysates. 
Table 5. Results of 3HP production from glucose using S. cerevisiae as host microorganism.

\begin{tabular}{|c|c|c|c|c|}
\hline Genes Transferred & Culture Conditions & $\begin{array}{l}\text { Concentration } \\
(\mathrm{g} / \mathrm{L})\end{array}$ & $\begin{array}{l}\text { Productivity } \\
(\mathrm{g} / \mathrm{L} \cdot \mathrm{h})\end{array}$ & Ref. \\
\hline $\begin{array}{l}\text { Multiple copies of } m c r \text { from C. aurantiacus } \\
\text { and mutant } a c c 1, a c s^{L 641 P} \text { from S. enterica, } \\
\text { overexpression of } p d c 1 \text { and ald6, gapdh } \\
\text { from C. acetobutylicum }\end{array}$ & $\begin{array}{l}\text { Fed-batch bioreactor } 1 \mathrm{~L}, \\
0.5 \mathrm{~L}, \mathrm{pH} 5,30^{\circ} \mathrm{C}, 2 \mathrm{vvm}, \\
800 \mathrm{rpm}\end{array}$ & 9.8 & 0.1 & [59] \\
\hline $\begin{array}{l}\text { yhxA from B. cereus, } y d f G \text { from } E . \text { coli, } \\
\text { panD from T. castaneum, overexpression } \\
\text { of aat } 2, p y c 1 \text {, and } p y c 2\end{array}$ & $\begin{array}{l}\text { Fed-batch bioreactor } 1 \mathrm{~L}, \\
0.5 \mathrm{~L}, \mathrm{pH} 5,30^{\circ} \mathrm{C}, 2 \mathrm{vvm}, \\
800 \mathrm{rpm}\end{array}$ & 13.7 & 0.17 & [48] \\
\hline $\begin{array}{l}\text { pyc1 and pyc2, bapat from B. cereus, panD } \\
\text { from T. castaneum, ydfG from E. coli }\end{array}$ & $\begin{array}{c}\text { Fed-batch bioreactor } 2.7 \mathrm{~L} \\
\text { on xylose, } 1 \mathrm{~L}, \mathrm{pH} 5,30^{\circ} \mathrm{C}, \\
1 \mathrm{vvm}, 600-1200 \mathrm{rpm}\end{array}$ & 7.4 & 0.06 & [60] \\
\hline
\end{tabular}

\subsection{Use of Other Host Microorganisms}

Apart from work with the two commonly used microorganisms (E. coli and S. cerevisiae) for the construction of a strain capable of transforming glucose (and in some cases xylose) to 3HP, a few other host microorganisms have also been used. The yeast Schizosaccharomyces pombe is one example; this microorganism showed good tolerance of low $\mathrm{pH}$ values, which can result the accumulation of 3HP [58]. The malonyl-CoA pathway was constructed in this yeast by overexpression of an endogenous acetyl-CoA carboxylase (cut6p gene) and heterologous expression of the $m c r$ gene from C. aurantiacus in a protease-deficient strain (aimed at protecting the secreted proteins from degradation). Supplementation of the culture broth with acetate was also beneficial for $3 \mathrm{HP}$ production; the $3 \mathrm{HP}$ concentration reached $3.5 \mathrm{~g} / \mathrm{L}$ (with a productivity of $0.03 \mathrm{~g} / \mathrm{L} \cdot \mathrm{h}$ ) during culture in flasks, which was further increased to $7.6 \mathrm{~g} / \mathrm{L}$ (with a productivity of $0.25 \mathrm{~g} / \mathrm{L} \cdot \mathrm{h}$ ) when high-density culture was used (Table 6).

Table 6. Results of 3HP production from glucose using other host microorganisms.

\begin{tabular}{|c|c|c|c|c|c|}
\hline Genes Transferred & Microorganism & Culture Conditions & $\begin{array}{l}\text { Concentration } \\
(\mathrm{g} / \mathrm{L})\end{array}$ & $\begin{array}{l}\text { Productivity } \\
(\mathrm{g} / \mathrm{L} \cdot \mathrm{h})\end{array}$ & Ref. \\
\hline $\begin{array}{l}m c r \text { from C. aurantiacus and } \\
\text { overexpression of } c u t 6 p\end{array}$ & S. pombe & $\begin{array}{c}\text { Flasks } 100 \mathrm{~mL} \text { with } \\
\text { high-density cultures, } \\
10 \mathrm{~mL}, 30^{\circ} \mathrm{C}, 250 \mathrm{rpm}\end{array}$ & 7.6 & 0.25 & [58] \\
\hline $\begin{array}{l}\text { pdu from K. pneumoniae, gpd1 and } \\
\text { gpp } 2 \text { from S. cerevisiae, gabD from } \\
\text { C. necator, xylAB from E. coli, araE } \\
\text { from C. glutamicum, deletion of } l d h A \text {, } \\
\text { pta-ackA, poxB, and glpK, and } \\
\text { replacement of } p t s H \text { with iolT1 and glk }\end{array}$ & C. glutamicum & $\begin{array}{c}\text { Fed-batch bioreactor } \\
5 \mathrm{~L}, 2 \mathrm{~L}, \mathrm{pH} 7.2,30^{\circ} \mathrm{C} \\
1 \mathrm{vvm}\end{array}$ & 62.6 & 0.87 & [53] \\
\hline $\begin{array}{l}\text { pdu from K. pneumoniae, gpd1 and } \\
\text { gpp } 2 \text { from S. cerevisiae, gabD from } \\
\text { C. necator, xylAB from E. coli, araE } \\
\text { from C. glutamicum, deletion of } l d h A \text {, } \\
\text { pta-ackA, poxB, and glpK, and } \\
\text { replacement of } p t s H \text { with iolT1 and glk }\end{array}$ & C. glutamicum & $\begin{array}{c}\text { Fed-batch bioreactor } \\
5 \mathrm{~L} \text { with glucose and } \\
\text { xylose, } 2 \mathrm{~L}, \mathrm{pH} 7.2, \\
30^{\circ} \mathrm{C}, 1 \mathrm{vvm}\end{array}$ & 54.8 & n.a. & [53] \\
\hline
\end{tabular}

n.a.: not available.

Another host microorganism that was used is the bacterium Corynebacterium glutamicum. Chen et al. [53] engineered a strain that could convert glucose and xylose to $3 \mathrm{HP}$ through glycerol as an intermediate. The pathway was constructed by using the $p d u$ operon from K. pneumonia, fusion of the gpd1 and gpp2 genes (which are involved in glycerol synthesis), and expression of the gabD aldehyde dehydrogenase (which was found to be the most efficient of the aldehyde dehydrogenases tested). Furthermore, genes involved in the formation of by-products were deleted in order to improve the carbon flux towards 3HP. The $\mathrm{ptsH}$ gene (encoding the phosphoenolpyruvate dependent phosphotransferase system, which is the main route for glucose uptake) was also replaced with the inositol permeases gene (iolT1) and glucokinase gene ( $g l k$ ); finally, to allow pentose utilization, the pentose transport genes $a r a E$ and the xylose catabolite gene $x y l A B$ were also expressed. The resulting strain produced $3 \mathrm{HP}$ at $37.4 \mathrm{~g} / \mathrm{L}$ and $35.4 \mathrm{~g} / \mathrm{L}$ when grown on glucose and xylose, respectively, in batch 
bioreactors. The amount of $3 \mathrm{HP}$ produced for the co-consumption of the two sugars was $36.2 \mathrm{~g} / \mathrm{L}$, with a conversion yield of $0.45 \mathrm{~g} / \mathrm{g}$. Cultivation in fed-batch bioreactors further improved the $3 \mathrm{HP}$ production to $62.6 \mathrm{~g} / \mathrm{L}(0.51 \mathrm{~g} / \mathrm{g})$ when growing only on glucose, and to $54.8 \mathrm{~g} / \mathrm{L}(0.49 \mathrm{~g} / \mathrm{g})$ when growing on a mixture of glucose and xylose.

\section{Production of 3HP from Other Sources}

One of the alternative carbon sources that have been used for the production of $3 \mathrm{HP}$ is propionic acid. For this reason, the propionyl-CoA pathway (which has already been described) was constructed in E. coli by transferring a propionyl-CoA dehydrogenase gene (pacd) from Candida rugora, a propionate-CoA transferase gene ( $p c t$ ) from Megasphaera elsdenii, and a 3-hydroxypropionyl-CoA dehydratase gene $(h p c d)$ from C. aurantiacus [51]. In addition, deletion of the $y g f H$ and $p r p C$ genes led to the production of 3HP at $2.2 \mathrm{~g} / \mathrm{L}$ (Table 7). The main drawback of using propionate is that it is not a low-cost carbon source, which affects the production cost of 3HP. Moreover, the conversion yield obtained in this work was relatively low (35.4\%). On the other hand, as the authors also suggested, more work should be conducted to fully understand and control the pathway, and propionyl-CoA could be derived from glucose through succinyl-CoA, thus avoiding the use of propionic acid.

Recent research has shown that $3 \mathrm{HP}$ can also be produced from hydrolysis of the toxic compound 3-hydroxypropionitrile, which is a platform chemical widely used in many organic syntheses for the production of medicines, pesticides, and polymeric compounds [61]. Hydrolysis of 3-hydroxypropionitrile can yield 3HP; however, the chemical hydrolysis is not an environmentally friendly process, as it requires the use of strong basic solutions and high temperatures, and generates hypersaline waste water [62]. Green methods for the hydrolysis of 3-hydroxypropionitrile involve the use of biocatalysts, such as enzymes or whole cells. Zhang et al. [63] tried to isolate microorganisms that had nitrile-hydrolyzing activity from environmental samples. During their work, they identified a yeast strain, Meyerozyma guilliermondii CGMCC12935, with nitrile-hydrolyzing activity. The catalytic activity of the resting yeast cells was found to be optimal at $55^{\circ} \mathrm{C}$ and at $\mathrm{pH} 7.5$, with the enzyme showing a broad activity against various nitriles (with 3-hydroxypropionitrile being among them). The authors also evaluated the effects of several metal ions and alcohols on the nitrilase activity, and the presence of $\mathrm{Ag}^{+}$and $\mathrm{Pb}^{2+}$ turned out to be inhibitory. During the bioconversion of 3-hydroxypropionitrile to $3 \mathrm{HP}$ from the resting yeast cells, addition of glucose was found to be beneficial for the conversion yield, which reached a production of $19.5 \mathrm{~g} / \mathrm{L} 3 \mathrm{HP}$ from $35.5 \mathrm{~g} / \mathrm{L}$ 3-hydroxypropionitrile. In another study, whole-cell biocatalysis was achieved by using recombinant $E$. coli cells harboring a particular nitrilase gene, which was selected among 15 different nitrilase genes tested [62]. The authors tested both free and immobilized cells, optimizing the incubation parameters for the highest bioconversion yields. The newly developed biocatalyst was very robust and capable of hydrolyzing up to approximately $320 \mathrm{~g} / \mathrm{L}$ 3-hydroxypropionitrile in $24 \mathrm{~h}$ when free cells were used. Immobilization of the cells allowed the use of a concentration of 3-hydroxypropionitrile as high as $497 \mathrm{~g} / \mathrm{L}$, which gave complete hydrolysis within $24 \mathrm{~h}$. The immobilized cells showed remarkable stability during the reusability trials, retaining their activity for 30 batches, with a production of $184.7 \mathrm{~g} / \mathrm{L} 3 \mathrm{HP}$ during these 30 batches, and a volumetric productivity of $36.9 \mathrm{~g} / \mathrm{L} \cdot \mathrm{h}$.

Despite the obvious focus on heterotrophic 3HP production from renewable resources, the interest of some research groups lies in studying autotrophic producers, such as photosynthetic cyanobacteria, which have the ability to transform sunlight and $\mathrm{CO}_{2}$ into a variety of compounds. After modifications by genetic engineering, the recombinant strains are also capable of producing $3 \mathrm{HP}$ through $\mathrm{CO}_{2}$ fixation by the Calvin cycle, and further transformation to phosphoenolpyruvate, which can be converted to 3HP by two newly developed pathways, namely the malonyl-CoA intermediate pathway and the $\beta$-alanine intermediate pathway $[64,65]$. 
Table 7. Results of 3HP production from carbon sources other than glycerol and glucose (sugars).

\begin{tabular}{|c|c|c|c|c|c|}
\hline Genes Transferred & Microorganism & Culture Conditions & $\begin{array}{l}\text { Concentration } \\
(\mathrm{g} / \mathrm{L})\end{array}$ & $\begin{array}{l}\text { Productivity } \\
(\mathrm{g} / \mathrm{L} \cdot \mathrm{h})\end{array}$ & Ref. \\
\hline $\begin{array}{l}\text { pacd from C. rugora, pct } \\
\text { from M. elsdenii and } h p c d \\
\text { from C. aurantiacus, and } \\
\text { deletion of } y g f H \text { and } p r p C\end{array}$ & E. coli & $\begin{array}{l}\text { Flasks } 100 \mathrm{~mL}, 20 \mathrm{~mL}, \mathrm{pH} 7,30^{\circ} \mathrm{C} \text {, } \\
200 \mathrm{rpm} \text {. Propionic acid as } \\
\text { carbon source }\end{array}$ & 2.2 & n.a. & [51] \\
\hline - & $\begin{array}{c}M . \\
\text { guilliermondii }\end{array}$ & $\begin{array}{l}\text { Flasks, } 20 \mathrm{~mL}, \mathrm{pH} 7.2,30^{\circ} \mathrm{C} \text {, } \\
120 \mathrm{rpm} \text {. Hydrolysis of } \\
\text { 3-hydroxypropionitrile with the } \\
\text { addition of glucose }\end{array}$ & 19.5 & 0.20 & [63] \\
\hline $\begin{array}{l}\text { Nitrilase from } \\
\text { environmental samples }\end{array}$ & E. coli & $\begin{array}{l}\text { Batch reaction with immobilized } \\
\text { cells with 3-hydroxypropionitrile, } \\
30^{\circ} \mathrm{C}\end{array}$ & 184.7 & 36.9 & [62] \\
\hline $\begin{array}{l}m c r \text { from C. aurantiacus, } \\
\text { overexpression of pnt } A B \\
\text { and } a c c B C A D-b i r A \text {, and } \\
\text { deletion of } p h a B \text { and } p t a\end{array}$ & $\begin{array}{l}\text { Synechocystis } \\
\text { sp. }\end{array}$ & $\begin{array}{l}\text { Flasks } 100 \mathrm{~mL}, 20 \mathrm{~mL}, \mathrm{pH} \text { 7.5, } \\
30^{\circ} \mathrm{C}, 150 \mathrm{rpm} \text {. From } \mathrm{CO}_{2}\end{array}$ & 0.84 & 0.006 & [64] \\
\hline $\begin{array}{l}\text { mcr from } S \text {. tokodaii and } \\
m s r \text { from } M \text {. sedula }\end{array}$ & S. elongates & Flasks, $50 \mathrm{~mL}, 30^{\circ} \mathrm{C}$. From $\mathrm{CO}_{2}$ & 0.67 & 0.002 & [65] \\
\hline $\begin{array}{l}\text { Ppc and aspC from E. coli, } \\
\text { SkPYD4 from S. kluyveri, } \\
\text { and msr from M. sedula }\end{array}$ & S. elongates & Flasks, $50 \mathrm{~mL}, 30^{\circ} \mathrm{C}$. From $\mathrm{CO}_{2}$ & 0.19 & 0.0005 & [65] \\
\hline
\end{tabular}

The first route involves the use of malonyl-CoA. In this case, phosphoenolpyruvate is transformed through pyruvate to acetyl-CoA, which is converted to malonyl-CoA by the action of acetyl-CoA carboxylase, a biotin-dependent enzyme. Finally, malonyl-CoA is converted to 3HP by malonyl-CoA reductase [64]. This pathway was constructed in the cyanobacterium Synechocystis sp. by transferring the $m c r$ gene from C. aurantiacus [64]. To improve the supply of NADPH and malonyl-CoA, the genes for $\mathrm{NAD}(\mathrm{P})$-transhydrogenase ( $p n t A B)$ and acetyl-CoA carboxylase and biotinilase (accBCAD-birA) were overexpressed. Finally, to improve the carbon flux towards $3 \mathrm{HP}$, the genes involved in the formation of PHA $(p h a B)$ and acetate ( $p t a)$ were deleted. The newly constructed strain was capable of producing approximately $0.84 \mathrm{~g} / \mathrm{L} 3 \mathrm{HP}$ directly from $\mathrm{CO}_{2}$. The malonyl-CoA route was also used by Lan et al. [65] for the construction of a recombinant Synechococcus elongatus strain. The authors expressed the $\mathrm{mcr}$ gene from Sulfolobus tokodaii and the malonate semialdehyde reductase gene ( $\mathrm{msr}$ ) from Metallosphaera sedula, which resulted in the production of $0.67 \mathrm{~g} / \mathrm{L}$ of $3 \mathrm{HP}$.

The second approach is to use the $\beta$-alanine intermediate pathway, where phosphoenolpyruvate is converted to oxaloacetate by the action of phosphoenolpyruvate carboxylase. Oxaloacetate is transformed by the action of aspartate transaminase to aspartate, which is then converted to $\beta$-alanine by the action of aspartate carboxylase. Finally, $\beta$-alanine is converted to malonate semialdehyde by the action of $\beta$-alanine aminotransferase, and finally, to $3 \mathrm{HP}$ by the action of malonate semialdehyde reductase [65]. Lan et al. [65] constructed this pathway in S. elongates cells by expressing the phosphoenolpyruvate carboxylase gene $(p p c)$ and the aspartate aminotransferase gene $(a s p C)$ from E. coli, together with the $\beta$-alanine aminotransferase gene (SkPYD4) from Saccharomyces kluyveri and the $m s r$ gene from $M$. sedula. Production of $3 \mathrm{HP}$ from $\mathrm{CO}_{2}$ was approximately $0.19 \mathrm{~g} / \mathrm{L}$, which was lower than the results obtained when $3 \mathrm{HP}$ was produced through the malonyl-CoA intermediate pathway. Although the results obtained from the direct conversion of $\mathrm{CO}_{2}$ to $3 \mathrm{HP}$ are still low, direct conversion of $\mathrm{CO}_{2}$ to high-value chemicals is a very promising process, and during the next year, more research work is expected to be devoted to this, with the aim of improving the conversion yields.

\section{Conclusions}

Biotechnological production of $3 \mathrm{HP}$ from renewable resources, the treatment of toxic compounds, and $\mathrm{CO}_{2}$ have been attracting considerable attention during the decades. Different routes and techniques are being established, with the goal of a sustainable fossil-free production of $3 \mathrm{HP}$. During the 
last four years, significant progress has been made in improving the production yields of $3 \mathrm{HP}$ from glycerol and glucose, which has resulted in improvement of the titers achieved, and also, the conversion yields. New approaches have also been proposed, such as systems for the hydrolysis of 3-hydroxypropionitrile, resulting in high concentrations of 3HP with concomitant treatment of a toxic compound. The very good results that have been obtained through all the research work conducted are an important step towards the commercial biotechnological production of $3 \mathrm{HP}$.

Acknowledgments: We thank Bio4Energy, a strategic research environment appointed by the Swedish government, for supporting this work.

Author Contributions: Leonidas Matsakas, Ulrika Rova, and Paul Christakopoulos conceived the article and planned the structure of the manuscript. Leonidas Matsakas and Kateřina Hrůzová searched and analyzed the literature and wrote the paper. All the authors have read, commented on, and approved the paper.

Conflicts of Interest: The authors declare that they have no conflicts of interest.

\section{References}

1. Werpy, T.; Petersen, G.; Aden, A.; Bozell, J.; Holladay, J.; White, J.; Manheim, A.; Eliot, D.; Lasure, L.; Jones, S. Top Value Added Chemicals from Biomass. Volume 1-Results of Screening for Potential Candidates from Sugars and Synthesis Gas; Department of Energy: Washington, DC, USA, 2004.

2. Rathnasingh, C.; Raj, S.M.; Jo, J.E.; Park, S. Development and evaluation of efficient recombinant Escherichia coli strains for the production of 3-hydroxypropionic acid from glycerol. Biotechnol. Bioeng. 2009, 104, 729-739. [CrossRef] [PubMed]

3. Matsakas, L.; Topakas, E.; Christakopoulos, P. New trends in microbial production of 3-hydroxypropionic acid. Curr. Biochem. Eng. 2015, 1, 141-154. [CrossRef]

4. Jung, W.S.; Kang, J.H.; Chu, H.S.; Choi, I.S.; Cho, K.M. Elevated production of 3-hydroxypropionic acid by metabolic engineering of the glycerol metabolism in Escherichia coli. Metab. Eng. 2014, 23, 116-122. [CrossRef] [PubMed]

5. Matsakas, L.; Giannakou, M.; Vörös, D. Effect of synthetic and natural media on lipid production from Fusarium oxysporum. Electron. J. Biotechnol. 2017, 30, 95-102. [CrossRef]

6. Yang, F.; Hanna, M.A.; Sun, R. Value-added uses for crude glycerol-A byproduct of biodiesel production. Biotechnol. Biofuels 2012, 5, 13. [CrossRef] [PubMed]

7. Okoye, P.U.; Hameed, B.H. Review on recent progress in catalytic carboxylation and acetylation of glycerol as a byproduct of biodiesel production. Renew. Sustain. Energy Rev. 2016, 53, 558-574. [CrossRef]

8. He, Q.; McNutt, J.; Yang, J. Utilization of the residual glycerol from biodiesel production for renewable energy generation. Renew. Sustain. Energy Rev. 2017, 71, 63-76. [CrossRef]

9. Rodrigues, A.; Bordado, J.C.; Dos Santos, R.G. Upgrading the glycerol from biodiesel production as a source of energy carriers and chemicals-A technological review for three chemical pathways. Energies 2017, 10, 1817. [CrossRef]

10. Garlapati, V.K.; Shankar, U.; Budhiraja, A. Bioconversion technologies of crude glycerol to value added industrial products. Biotechnol. Rep. 2016, 9, 9-14. [CrossRef] [PubMed]

11. Ashok, S.; Raj, S.M.; Rathnasingh, C.; Park, S. Development of recombinant Klebsiella pneumoniae $\triangle d h a T$ strain for the co-production of 3-hydroxypropionic acid and 1,3-propanediol from glycerol. Appl. Microbiol. Biotechnol. 2011, 90, 1253-1265. [CrossRef] [PubMed]

12. Ko, Y.; Seol, E.; Sundara Sekar, B.; Kwon, S.; Lee, J.; Park, S. Metabolic engineering of Klebsiella pneumoniae J2B for co-production of 3-hydroxypropionic acid and 1,3-propanediol from glycerol: Reduction of acetate and other by-products. Bioresour. Technol. 2017, 244, 1096-1103. [CrossRef] [PubMed]

13. Chen, X.; Xiu, Z.; Wang, J.; Zhang, D.; Xu, P. Stoichiometric analysis and experimental investigation of glycerol bioconversion to 1,3-propanediol by Klebsiella pneumoniae under microaerobic conditions. Enzyme Microb. Technol. 2003, 33, 386-394. [CrossRef]

14. Zaushitsyna, O.; Dishisha, T.; Hatti-Kaul, R.; Mattiasson, B. Crosslinked, cryostructured Lactobacillus reuteri monoliths for production of 3-hydroxypropionaldehyde, 3-hydroxypropionic acid and 1,3-propanediol from glycerol. J. Biotechnol. 2017, 241, 22-32. [CrossRef] [PubMed] 
15. Ko, Y.; Ashok, S.; Ainala, S.K.; Sankaranarayanan, M.; Chun, A.Y.; Jung, G.Y.; Park, S. Coenzyme B $B_{12}$ can be produced by engineered Escherichia coli under both anaerobic and aerobic conditions. Biotechnol. J. 2014, 9, 1526-1535. [CrossRef] [PubMed]

16. Lawrence, J.G.; Roth, J.R. Evolution of coenzyme $B_{12}$ synthesis among enteric bacteria: Evidence for loss and reacquisition of a multigene complex. Genetics 1996, 142, 11-24. [PubMed]

17. Toraya, $\mathrm{T}$. Radical catalysis in coenzyme $\mathrm{B}_{12}$-dependent isomerization (eliminating) reactions. Chem. Rev. 2003, 103, 2095-2127. [CrossRef] [PubMed]

18. Daniel, R.; Bobik, T.A.; Gottschalk, G. Biochemistry of coenzyme B12-dependent glycerol and diol dehydratases and organization of the encoding genes. FEMS Microbiol. Rev. 1998, 22, 553-566. [CrossRef] [PubMed]

19. Zhang, G.L.; Xu, X.L.; Li, C.; Ma, B. Bin Cloning, expression and reactivating characterization of glycerol dehydratase reactivation factor from Klebsiella pneumoniae XJPD-Li. World J. Microbiol. Biotechnol. 2009, 25, 1947-1953. [CrossRef]

20. Ashok, S.; Sankaranarayanan, M.; Ko, Y.; Jae, K.E.; Ainala, S.K.; Kumar, V.; Park, S. Production of 3-hydroxypropionic acid from glycerol by recombinant Klebsiella pneumoniae $\Delta$ dhaT $\Delta y q h D$ which can produce vitamin $\mathrm{B}_{12}$ naturally. Biotechnol. Bioeng. 2013, 110, 511-524. [CrossRef] [PubMed]

21. Luo, L.H.; Seo, J.W.; Baek, J.O.; Oh, B.R.; Heo, S.Y.; Hong, W.K.; Kim, D.H.; Kim, C.H. Identification and characterization of the propanediol utilization protein PduP of Lactobacillus reuteri for 3-hydroxypropionic acid production from glycerol. Appl. Microbiol. Biotechnol. 2011, 89, 697-703. [CrossRef] [PubMed]

22. Bobik, T.A.; Havemann, G.D.; Busch, R.J.; Williams, D.S.; Aldrich, H.C. The propanediol utilization ( $p d u)$ operon of Salmonella enterica serovar Typhimurium LT2 includes genes necessary for formation of polyhedral organelles involved in coenzyme B 12 -dependent 1,2-propanediol degradation. J. Bacteriol. 1999, 181, 5967-5975. [PubMed]

23. Dishisha, T.; Pereyra, L.P.; Pyo, S.H.; Britton, R.A.; Hatti-Kaul, R. Flux analysis of the Lactobacillus reuteri propanediol-utilization pathway for production of 3-hydroxypropionaldehyde, 3-hydroxypropionic acid and 1,3-propanediol from glycerol. Microb. Cell Fact. 2014, 13. [CrossRef] [PubMed]

24. Johnsont, E.A.; Lin, E.C.C. Klebsiella pneumoniae 1,3-Propanediol:NAD ${ }^{+}$Oxidoreductase. J. Bacteriol. 1987, 169, 2050-2054. [CrossRef]

25. Wang, K.; Tian, P. Engineering plasmid-free Klebsiella pneumoniae for production of 3-hydroxypropionic acid. Curr. Microbiol. 2017, 74, 55-58. [CrossRef] [PubMed]

26. Podschun, R.; Ullmann, U. Klebsiella spp. as nosocomial pathogens: Epidemiology, taxonomy, typing methods, and pathogenicity factors. Clin. Microbiol. Rev. 1998, 11, 589-603. [PubMed]

27. Su, M.; Li, Y.; Ge, X.; Tian, P. 3-Hydroxypropionaldehyde-specific aldehyde dehydrogenase from Bacillus subtilis catalyzes 3-hydroxypropionic acid production in Klebsiella pneumoniae. Biotechnol. Lett. 2015, 37, 717-724. [CrossRef] [PubMed]

28. Huang, Y.; Li, Z.; Shimizu, K.; Ye, Q. Co-production of 3-hydroxypropionic acid and 1,3-propanediol by Klebseilla pneumoniae expressing aldH under microaerobic conditions. Bioresour. Technol. 2013, 128, 505-512. [CrossRef] [PubMed]

29. Li, Y.; Wang, X.; Ge, X.; Tian, P. High production of 3-hydroxypropionic acid in Klebsiella pneumoniae by systematic optimization of glycerol metabolism. Sci. Rep. 2016, 6, 26932. [CrossRef] [PubMed]

30. Zhao, L.; Lin, J.; Wang, H.; Xie, J.; Wei, D. Development of a two-step process for production of 3-hydroxypropionic acid from glycerol using Klebsiella pneumoniae and Gluconobacter oxydans. Bioprocess Biosyst. Eng. 2015, 38, 2487-2495. [CrossRef] [PubMed]

31. Niu, K.; Cheng, X.L.; Qin, H.B.; Liu, J.S.; Zheng, Y.G. Investigation of the key factors on 3-hydroxypropionic acid production with different recombinant strains. 3 Biotech 2017, 7, 314. [CrossRef] [PubMed]

32. Kumar, V.; Ashok, S.; Park, S. Recent advances in biological production of 3-hydroxypropionic acid. Biotechnol. Adv. 2013, 31, 945-961. [CrossRef] [PubMed]

33. Lim, H.G.; Noh, M.H.; Jeong, J.H.; Park, S.; Jung, G.Y. Optimum rebalancing of the 3-hydroxypropionic acid production pathway from glycerol in Escherichia coli. ACS Synth. Biol. 2016, 5, 1247-1255. [CrossRef] [PubMed]

34. Chu, H.S.; Kim, Y.S.; Lee, C.M.; Lee, J.H.; Jung, W.S.; Ahn, J.H.; Song, S.H.; Choi, I.S.; Cho, K.M. Metabolic engineering of 3-hydroxypropionic acid biosynthesis in Escherichia coli. Biotechnol. Bioeng. 2015, 112, 356-364. [CrossRef] [PubMed] 
35. Sankaranarayanan, M.; Somasundar, A.; Seol, E.; Chauhan, A.S.; Kwon, S.; Jung, G.Y.; Park, S. Production of 3-hydroxypropionic acid by balancing the pathway enzymes using synthetic cassette architecture. J. Biotechnol. 2017, 259, 140-147. [CrossRef] [PubMed]

36. Niu, K.; Xiong, T.; Qin, H.B.; Wu, H.; Liu, Z.Q.; Zheng, Y.G. 3-Hydroxypropionic acid production by recombinant Escherichia coli ZJU-3HP01 using glycerol-glucose dual-substrate fermentative strategy. Biotechnol. Appl. Biochem. 2017, 64, 572-578. [CrossRef] [PubMed]

37. Sankaranarayanan, M.; Ashok, S.; Park, S. Production of 3-hydroxypropionic acid from glycerol by acid tolerant Escherichia coli. J. Ind. Microbiol. Biotechnol. 2014, 41, 1039-1050. [CrossRef] [PubMed]

38. Tsuruno, K.; Honjo, H.; Hanai, T. Enhancement of 3-hydroxypropionic acid production from glycerol by using a metabolic toggle switch. Microb. Cell Fact. 2015, 14, 155. [CrossRef] [PubMed]

39. Honjo, H.; Tsuruno, K.; Tatsuke, T.; Sato, M.; Hanai, T. Dual synthetic pathway for 3-hydroxypropionic acid production in engineered Escherichia coli. J. Biosci. Bioeng. 2015, 120, 199-204. [CrossRef] [PubMed]

40. Amin, H.M.; Hashem, A.M.; Ashour, M.S.; Hatti-Kaul, R. 1,2 Propanediol utilization by Lactobacillus reuteri DSM 20016, role in bioconversion of glycerol to 1,3 propanediol, 3-hydroxypropionaldehyde and 3-hydroxypropionic acid. J. Genet. Eng. Biotechnol. 2013, 11, 53-59. [CrossRef]

41. Dishisha, T.; Pyo, S.H.; Hatti-Kaul, R. Bio-based 3-hydroxypropionic- and acrylic acid production from biodiesel glycerol via integrated microbial and chemical catalysis. Microb. Cell Fact. 2015, 14, 200. [CrossRef] [PubMed]

42. Kalantari, A.; Chen, T.; Ji, B.; Stancik, I.A.; Ravikumar, V.; Franjevic, D.; Saulou-Bérion, C.; Goelzer, A.; Mijakovic, I. Conversion of glycerol to 3-hydroxypropanoic acid by genetically engineered Bacillus subtilis. Front. Microbiol. 2017, 8, 638. [CrossRef] [PubMed]

43. Sjöblom, M.; Matsakas, L.; Krige, A.; Rova, U.; Christakopoulos, P. Direct electricity generation from sweet sorghum stalks and anaerobic sludge. Ind. Crops Prod. 2017, 108, 505-511. [CrossRef]

44. Matsakas, L.; Nitsos, C.; Vörös, D.; Rova, U.; Christakopoulos, P. High-titer methane from organosolv-pretreated spruce and birch. Energies 2017, 10, 263. [CrossRef]

45. Nitsos, C.; Matsakas, L.; Triantafyllidis, K.; Rova, U.; Christakopoulos, P. Investigation of different pretreatment methods of Mediterranean-type ecosystem agricultural residues: Characterisation of pretreatment products, high-solids enzymatic hydrolysis and bioethanol production. Biofuels 2017, 1-14. [CrossRef]

46. Matsakas, L.; Rova, U.; Christakopoulos, P. Strategies for enhanced biogas generation through anaerobic digestion of forest material-An overview. BioResources 2016, 11, 5482-5499. [CrossRef]

47. Choi, S.; Song, C.W.; Shin, J.H.; Lee, S.Y. Biorefineries for the production of top building block chemicals and their derivatives. Metab. Eng. 2015, 28, 223-239. [CrossRef] [PubMed]

48. Borodina, I.; Kildegaard, K.R.; Jensen, N.B.; Blicher, T.H.; Maury, J.; Sherstyk, S.; Schneider, K.; Lamosa, P.; Herrgård, M.J.; Rosenstand, I.; et al. Establishing a synthetic pathway for high-level production of 3-hydroxypropionic acid in Saccharomyces cerevisiae via $\beta$-alanine. Metab. Eng. 2015, 27, 57-64. [CrossRef] [PubMed]

49. Song, C.W.; Kim, J.W.; Cho, I.J.; Lee, S.Y. Metabolic engineering of Escherichia coli for the production of 3-hydroxypropionic acid and malonic acid through $\beta$-alanine route. ACS Synth. Biol. 2016, 5, 1256-1263. [CrossRef] [PubMed]

50. Hasegawa, J.; Ogura, M.; Kanema, H.; Kawaharada, H.; Watanabe, K. Production of $\beta$-hydroxypropionic acid from propionic acid by a Candida rugosa mutant unable to assimilate propionic acid: Studies on $\beta$-hydroxycarboxylic acids (IV). J. Ferment. Technol. 1982, 60, 591-594.

51. Luo, H.; Zhou, D.; Liu, X.; Nie, Z.; Quiroga-Sánchez, D.L.; Chang, Y. Production of 3-hydroxypropionic acid via the propionyl-CoA pathway using recombinant Escherichia coli strains. PLoS ONE 2016, 11, e0156286. [CrossRef] [PubMed]

52. Burgard, A.P.; Dien van, S.J. Methods and Organisms for Growth-Coupled Production of 3-Hydroxypropionic Acid. U.S. Patent 2008/0199926 A1, 22 January 2008.

53. Chen, Z.; Huang, J.; Wu, Y.; Wu, W.; Zhang, Y.; Liu, D. Metabolic engineering of Corynebacterium glutamicum for the production of 3-hydroxypropionic acid from glucose and xylose. Metab. Eng. 2017, 39, 151-158. [CrossRef] [PubMed] 
54. Cheng, Z.; Jiang, J.; Wu, H.; Li, Z.; Ye, Q. Enhanced production of 3-hydroxypropionic acid from glucose via malonyl-CoA pathway by engineered Escherichia coli. Bioresour. Technol. 2016, 200, 897-904. [CrossRef] [PubMed]

55. Liu, C.; Ding, Y.; Zhang, R.; Liu, H.; Xian, M.; Zhao, G. Functional balance between enzymes in malonyl-CoA pathway for 3-hydroxypropionate biosynthesis. Metab. Eng. 2016, 34, 104-111. [CrossRef] [PubMed]

56. Song, C.W.; Lee, J.; Ko, Y.S.; Lee, S.Y. Metabolic engineering of Escherichia coli for the production of 3-aminopropionic acid. Metab. Eng. 2015, 30, 121-129. [CrossRef] [PubMed]

57. Jung, I.Y.; Lee, J.W.; Min, W.K.; Park, Y.C.; Seo, J.H. Simultaneous conversion of glucose and xylose to 3-hydroxypropionic acid in engineered Escherichia coli by modulation of sugar transport and glycerol synthesis. Bioresour. Technol. 2015, 198, 709-716. [CrossRef] [PubMed]

58. Suyama, A.; Higuchi, Y.; Urushihara, M.; Maeda, Y.; Takegawa, K. Production of 3-hydroxypropionic acid via the malonyl-CoA pathway using recombinant fission yeast strains. J. Biosci. Bioeng. 2017, 124, 392-399. [CrossRef] [PubMed]

59. Kildegaard, K.R.; Jensen, N.B.; Schneider, K.; Czarnotta, E.; Özdemir, E.; Klein, T.; Maury, J.; Ebert, B.E.; Christensen, H.B.; Chen, Y.; et al. Engineering and systems-level analysis of Saccharomyces cerevisiae for production of 3-hydroxypropionic acid via malonyl-CoA reductase-dependent pathway. Microb. Cell Fact. 2016, 15, 53. [CrossRef] [PubMed]

60. Kildegaard, K.R.; Wang, Z.; Chen, Y.; Nielsen, J.; Borodina, I. Production of 3-hydroxypropionic acid from glucose and xylose by metabolically engineered Saccharomyces cerevisiae. Metab. Eng. Commun. 2015, 2, 132-136. [CrossRef]

61. Xu, S.; Xiang, A.; Ying, A. Purification of 3-hydroxypropionitrile by wiped molecular distillation. Sci. China Ser. B 2004, 47, 521. [CrossRef]

62. Yu, S.; Yao, P.; Li, J.; Ren, J.; Yuan, J.; Feng, J.; Wang, M.; Wu, Q.; Zhu, D. Enzymatic synthesis of 3-hydroxypropionic acid at high productivity by using free or immobilized cells of recombinant Escherichia coli. J. Mol. Catal. B Enzym. 2016, 129, 37-42. [CrossRef]

63. Zhang, Q.; Gong, J.S.; Dong, T.T.; Liu, T.T.; Li, H.; Dou, W.F.; Lu, Z.M.; Shi, J.S.; Xu, Z.H. Nitrile-hydrolyzing enzyme from Meyerozyma guilliermondii and its potential in biosynthesis of 3-hydroxypropionic acid. Bioprocess Biosyst. Eng. 2017, 40, 901-910. [CrossRef] [PubMed]

64. Wang, Y.; Sun, T.; Gao, X.; Shi, M.; Wu, L.; Chen, L.; Zhang, W. Biosynthesis of platform chemical 3-hydroxypropionic acid (3-HP) directly from $\mathrm{CO}_{2}$ in cyanobacterium Synechocystis sp. PCC 6803. Metab. Eng. 2016, 34, 60-70. [CrossRef] [PubMed]

65. Lan, E.I.; Chuang, D.S.; Shen, C.R.; Lee, A.M.; Ro, S.Y.; Liao, J.C. Metabolic engineering of cyanobacteria for photosynthetic 3-hydroxypropionic acid production from $\mathrm{CO}_{2}$ using Synechococcus elongatus PCC 7942. Metab. Eng. 2015, 31, 163-170. [CrossRef] [PubMed] 